\title{
Household Position, Parenthood, and Self-reported Adult Health. Cross-Sectional and Longitudinal Evidence from the Austrian Generations and Gender Survey
}

\author{
Isabella Buber-Ennser and Doris Hanappi
}

\section{Introduction}

Family contexts have become increasingly heterogeneous in western Europe in this century, and Austria is a country of remarkable postponement of parenthood and a high prevalence of premarital cohabitation (Elzinga and Liefbroer 2007). This overall development has fueled interest among social scientists to examine the importance of family structures and the composition of a variety of societal outcomes, including health. Numerous studies have focused on well-being (captured via quality of life) (Wahrendorf and Siegrist 2010), mental health and depression (Khalaila and Litwin 2014; Ball et al. 2009), major diseases and disability as well as physical and cognitive functioning (Avendano et al. 2009; Hank et al. 2013). A central argument is that individuals' physical and mental health, and more generally their well-being, depends not only on their genetic disposition but is also influenced by social context.

From a life-course perspective, human beings share their lives with parents, siblings, partners, children, relatives, friends, neighbours, and colleagues. The relational and institutional embedding and shared events - or the lack of eventsover the life course as well as personal characteristics and the needs of those involved have a large influence on an individual's health. The term "linked lives"

\footnotetext{
I. Buber-Ennser $(\square)$

Wittgenstein Centre (IIASA, VID/ÖAW, WU), Vienna Institute of Demography/Austrian Academy of Sciences, Vienna, Austria e-mail: Isabella.Buber-Ennser@oeaw.ac.at

D. Hanappi

University of California, Berkeley, Berkeley, USA

e-mail: dorish@demog.berkeley.edu

D. Hanappi

Austrian Academy of Sciences (ÖAW), Vienna, Austria
}

(C) The Author(s) 2018

G. Doblhammer and J. Gumà (eds.), A Demographic Perspective on Gender,

Family and Health in Europe, https://doi.org/10.1007/978-3-319-72356-3_8 
(Elder 1995) has become an accepted, powerful synonym for situations in which effects occurring in one life domain (e.g. the family) spill over to another domain (e.g. health, work). In a family, there are members who enter or exit a union, become parents, or who form new unions. Such transitions and family events lead to changes in the physical and mental situations of men and women, key aspects being the gendered nature of family structure and household composition and the different gender norms that govern representations and practices of appropriate family roles for men and women (see Oláh, Kotowska and Richter in this book). This indicates attitudes and norms that expect men and women to fulfill different roles in the family - as caregivers, breadwinners, or sons/daughters. Gendered practices are not necessarily perceived as unfair, instead they are mentioned in discourses on the partners' freedom of choice and preferences or their abilities to perform given tasks (Bernardi et al. 2013). In turn, these choices and preferences lead to gender-specific practices within the family context over time, which in turn produces distinct health outcomes for men and women.

In order to understand the dynamics of health in families over the life course, we adopt a longitudinal perspective. Only a few longitudinal studies to date have focused on this topic, but the launch of European panel data comprising detailed information on demographic events, partnership, socio-economic characteristics, living arrangements, and subjective well-being allows individuals to be studied over time and to examine not only the household constellation and health of women and men, but also changes over time. These data are therefore highly suitable for assessing the link between changes in family structure and household position and changes in subjective health, and to disentangle the causal relationship between the two components. Austria participates in the Generations and Gender Survey (GGS), a European longitudinal survey, the two waves of which were carried out in 2008/9 and 2012/3. This is a unique opportunity to combine micro data on demographic events, partner and socio-economic status, living arrangements, and subjective well-being which thus allows the study of changes over time. Our findings are based on the rich GGS data and examine women's and men's health in young and middle adulthood from a household and family perspective. We focus on the reproductive years of respondents in the Austrian context from a cross-sectional and a longitudinal perspective while concentrating on the household position by gender (in the cross-sectional models) and accounting for partner status and the existence of pre-union children, parity, and the arrival of a newborn child. While our primary interest is on the general relationships between individuals' family contexts and different health outcomes, we include non-standard living arrangements, especially stepfamilies and individuals living apart together. 


\section{Household Position and Adult Health}

Although there are well-known universalities in the family-health nexus, it is important to place households in their particular historical social context (see also Hank and Steinbach in this book). This includes properly accounting for the growing heterogeneity of household compositions, which implies that considering only standard living arrangements (e.g. marriage) is no longer sufficient anymore for understanding how, for example, living with a partner within the same household or in separate households affects health (e.g. Schneider et al. 2014).

In this context, the term 'de-institutionalization' of the life course has become accepted and is now a synonym for the process by which the social and temporal organization of the life course becomes less guided by normative, legal, or organizational rules (Elzinga and Liefbroer 2007). This concept is particularly useful when studying changes in household position and the occurrence of events (union formation, separation, birth) and their effects on different life domains, such as health, as it implies that the occurrence and particularly the sequencing of events becomes less clear and that the likelihood of combining multiple roles within the family increases. Brückner and Mayer (2005) suggested that family lives are becoming more differentiated, implying an increase in the number of family-related states and an emphasis on the rise of new types of living arrangements. A second aspect in the de-standardization of family lives implies that these are becoming less similar to one another and that the domination of specific family contexts is weakening. This applies in particular to married couples living with one or two children of their own.

Marriage has largely been found to improve health in the short and long term, with numerous studies examining the association between marital status and health (for a discussion of selection issues see Hank and Steinbach in this volume). Married individuals report better self-assessed health, have lower rates of long-term illness, are less depressed, and live longer than their unmarried counterparts (Hemström 1996; Lillard and Waite 1995; Ross et al. 1990). Three explanations are given for this link between marital status with health. First, marriage is a marital resource which impacts health through better access to economic resources, social support, and regulation of health behaviours that married individuals have (Ross et al. 1990). Second, health selection into marriage is crucial (Goldman 1993). In a longitudinal study, Joung et al. (1998) showed that married people who reported various health complaints or chronic conditions were significantly more likely to become divorced than people without these health problems. More recently Koball et al. (2010) confirmed this health selection into marriage using data on African Americans. Similarly, a longitudinal study by Brockmann and Klein (2004) provided empirical evidence that marriage, especially a long-lasting first marriage, had positive health effects which accumulated over time and thus promoted longevity. Third, the marital differences in health exist primarily because the strains of marital dissolution decrease health (Booth and Amato 1991; Amato 2000). The latter perspective, however, only explains temporary health declines after a marital 
dissolution; it assumes similar health outcomes for the married and those long after a transition out of marriage (i.e. divorced or widowed). Previous studies of the health effects of marital status have confirmed primarily short-term effects on mental health (Booth and Amato 1991; Amato and Hohmann-Marriott 2007).

Since the 1970s, cohabitation has gained increasing interest as a new type of living arrangement (Beaujouan and Bhrolcháin 2011), and numerous studies have shown that its prevalence has been steadily increasing across Europe and in the US (Perelli-Harris et al. 2014; Heuveline and Timberlake 2004). Whereas premarital cohabitation delays entrance into marriage, it has not become a long-term alternative to marriage, especially when raising children (Perelli-Harris and Lyons-Amos 2015; Perelli-Harris et al. 2012). In the context of health, cohabitation is less researched than its traditional counterpart of marriage, partly because cohabitation has often been a preliminary stage to marriage and thus involves younger individuals in particular. Findings on the link between cohabitation and health are mixed. On the one hand, research finds no mental health differences between cohabiting and married or single individuals (Horwitz and White 1998), and similar results were obtained in a study comparing cohabiting and married individuals (Horwitz and White 1998; Marcussen 2005). On the other hand, in a study comparing cohabiting and married individuals using the 1998 Health and Retirement Study, Brown et al. (2005) found that cohabitors report more depressive symptoms on average than do married couples, net of economic resources, social support, and physical health. Moreover, cohabitation is associated with more risky behaviour (Horwitz and White 1998).

These differences are largely explained by whether young or older adults are examined, cross-sectional or longitudinal design are used, and by the comparison group chosen. If less emphasis is placed on marital status and more on household position, we expect that individuals living together with a partner would report better health than those not living in a couple context. A major reason for this is that living together with a partner - especially in middle adulthood - corresponds to the 'normative life course'.

There is substantial evidence linking partnership quality to health. Marital happiness and marital problems are significantly associated with physical health, and marital strain accelerates the decline in self-rated health (Miller et al. 2013; Umberson et al. 2006). Thus, we expect a positive association between partnership quality and subjective well-being.

Divorce is still a critical life event for both partners, and individual characteristics are crucial for health outcomes (Amato 2010; Holmes and Rahe 1967). Cross-sectional studies have provided evidence for the negative health effects of marital disruption (Aseltine and Kessler 1993; Ren 1997). Fewer studies have looked at the aspect of personal growth, as a psychological aspect, through divorce and separation. Perrig-Chiello and Knöpfli's longitudinal study (2015) of separation impacts on mental health finds recovery effects after divorce: They show that women reported higher depressive symptoms and perceived stress and loneliness during and after separation, whereas men were more likely to report higher levels of social isolation. At the same time, women recovered from separation within two 
years, whereas no similar effect was observed for men. In line with these arguments, we expect separation in Austria to harm subjective health in the short and medium term, which is expressed by lower self-assessed health after separation.

Living apart together (LAT) relationships, where partners maintain separate households and finances, are becoming more common in northern and western Europe (Davidson 2002; De Jong Gierveld 2004; Karlsson and Borell 2002; Castro-Martín et al. 2008). This type of partnership is prevalent also at older ages and is a preliminary stage of the courtship process potentially leading to cohabitation. In Europe today, unmarried cohabitation and living apart together relationships are frequently opted for on re-partnering after bereavement or divorce, even at higher ages (De Jong Gierveld 2004). Individuals in intimate non-cohabiting relationships are a heterogeneous group, including young adults, women living alone with their children after separation, and older persons. The main explanations for not sharing a household are a wish to remain independent, financial constraints, and work issues (Régnier-Loilier et al. 2009). However, studies on the link between non-cohabiting relationships and health of individuals in this living arrangement are rather scarce. We expect that having an LAT partner in young and middle adulthood to be positively associated with health as opposed to individuals reporting no intimate relationship.

\section{Parenthood and Adult Health}

A large number of family studies have focused on the association between responsibilities related to raising children and health outcomes (for an overview see Uhlenberg and Mueller 2003). In this context, scholars have also recently explored the relationship between happiness and childbearing (Baranowska and Matysiak 2011; Aassve et al. 2012; Myrskylä and Margolis 2014; Kohler et al. 2005). To explain childbearing and health, three explanations are most common: First, economic and rational-choice approaches to parenthood assume that individuals derive 'utility' from having children and that their decisions are based on the gains achieved by having children as compared to utility gains that are incurred from alternative allocations of resources, such as income and time, which are also required to maintain partnerships and raise children. Recent studies suggest that utility can be investigated empirically by using measures of subjective well-being (Stutzer and Frey 2010). Assuming that individuals have no misconceptions about childbearing and make conscious and informed decisions, one would expect that children would increase happiness. Second, Easterlin (2006) notes that significant life events, such as the birth of a child, only transitorily change an individual's well-being from a setpoint that is determined by personality traits and genetic factors. In this perspective, individuals restore their well-being to a predetermined setpoint after the birth of a child (see Kohler et al. 2005). In line with this, happiness increases in the years around the birth of a first child and then decreases to before-child levels (Myrskylä and Margolis 2014). Third, role-identity theory 
(Stryker 1980) accounts for gender differences in social roles linked with socially constructed behavioural expectations. Fulfilling the parent role and simultaneously performing other roles as a partner, son/daughter, or employee may cause conflicting behavioural expectations leading to role overload and thus decreased well-being (Marks 1998). It is possible that having children increases demands from the family and thereby generates role overload. These demands arising from parenthood are highly gendered (Voydanoff 2005). In summary, economic and role-theoretic models expect women who take on most of the care burden to experience most of the decrease in subjective health when having children. Given the gendered division of childcare and household duties in Austria (Berghammer 2014; Buber-Ennser 2015), we anticipate negative health outcomes for mothers of two or more children. There is, however, sufficient variation in health outcomes depending on the age of the youngest child in the home (Hanappi 2012), the positive health effect of having school children (Mason and Kuhltau 1989), and the overall number of children in a household. Especially the birth of the first child has a positive effect on the subjective well-being of mothers (Baranowska and Matysiak 2011; Myrskylä and Margolis 2014). Accordingly, we expect a positive effect of the birth of a child on health.

Lone parents are an increasingly important group in contemporary Western populations. Numerous studies have shown that lone parents have a poorer health status than the general population (Franz and Lensche 2003; Benzeval 1998; Witvliet et al. 2014; Van de Velde et al. 2014). Although health differences mirror variations in socioeconomic circumstances, lone mothers in particular have significantly poorer health than couple mothers, even after controlling for a wide range of demographic and socioeconomic circumstances. The absence of an intimate relationship, the stress and stigma associated with being a lone parent, and health selection might be alternative explanations for health differences between lone and couple parents (Benzeval 1998; Vingilis et al. 1998). We anticipate lone mothers will have worse self-perceived health compared to mothers co-residing with a partner.

A last group of interest are stepfamilies - a group that has higher rates of separation and divorce, with childbearing extending over several partnerships (Beaujouan and Solaz 2013; Beaujouan 2011; Bumpass et al. 1995; Thomson et al. 2002, 2012). Stepfamilies have become an important object of study (Thomson 1997, 2004; Vikat et al. 1999; Thomson 2014; Thomson et al. 2014). In the late 1970s, Furstenberg (1979) already observed that this process of "recycling the family" had replaced the nuclear family with distinct implications for kinship systems. Due to changes in traditional family structures, the term stepfamilies, formerly restricted to marriages, has been extended and now includes cohabiting unions with at least one child from a previous union (Bumpass et al. 1995). Recently, the terms 'multi-partner fertility' and 'complex families' have been used to describe adults having children with more than one person (Meyer et al. 2005; Evenhouse and Reilly 2012; Thomson 2014). Studies on stepfamilies in demography have focused mainly on childbearing and dissolution. Another vein of research examines children's health, behaviour, support, and school achievement in 
such families (Bronte-Tinkew et al. 2009; Guzzo 2009; Osborne and McLanahan 2007). Empirical evidence from the US shows that children and adolescents in single-parent or stepfather families reported significantly poorer physical and mental health than persons living with both biological parents (Heard et al. 2008; Dawson 1991). The health of parents in complex families has rarely been investigated, and insights from the well-being of (mainly) mothers and fathers in stepfamilies largely stem from the US and also reveal negative effects for adults. Mothers with children by more than one father report lower support and are more prone to depressive symptoms than mothers with children by only one partner (Harknett and Knab 2007; Turney and Carlson 2011). Parental health in stepfamilies still constitutes an area open for research in the European context. The potential negative effect of the well-being of individuals in multipartnered families is expected to correlate with economic, psychological, and social deprivation. Social selection may comprise part of the link between well-being and multi-partnered families; health disadvantages and stepfamilies may be "reciprocally related and part of broader processes of social disadvantage" (Turney and Carlson 2011, p. 570). If people of a lower socio-economic status and well-being are more likely to enter into multi-partnered families (see. e.g. Treviño and Gumà (2013) for disadvantaged divorced individuals entering remarriage in Spain), we might easily associate such a multi-partnered context with lower well-being.

\section{Data and Methods}

The current study is based on the first two waves of the Austrian Generations and Gender Survey (GGS). The first wave took place in 2008/9 and included 5001 respondents aged 18-44, the second wave was carried out four years later in 2012/ 13. In total $78 \%$ of wave 1 respondents were interviewed again in wave 2, corresponding to a relatively low panel dropout of 22\% (Buber-Ennser 2014). Overall, the Austrian GGS panel data can be used without (significant) concern about selectivity (Buber-Ennser 2014) and are a valuable source for studying living arrangements and health as well as their dynamics over a period of four years.

The main variables used in our study include two crucial dimensions, living arrangements and health. Individuals' health is measured based on self-perceived health status, from the question "How is your health in general?" Possible answers were (1) very good, (2) good, (3) fair, (4) bad, and (5) very bad. This is a powerful measure of health, as studies have consistently found that it is an independent predictor of mortality (Idler and Benyamini 1997). Nevertheless, recent findings indicate that the predictive capacity of self-perceived health on mortality decreases for old and late old ages (Woo and Zajacova 2015). For the descriptive results we keep part of the detailed levels and give means. For multivariate analyses these are categorized into a binary health variable "(very) good" and "fair or worse". For the sake of simplicity, we denote those with fair, bad, or very bad health as being in poor health, and those with good or very good health as being in good health. 
We focus on the individual's position within the household according to (1) partnership situation (living or not with a partner), (2) living with children, and (3) the relationship within the family nucleus (member or not of the nucleus). As the age of the target population is $18-44$, this differentiation is important for this period encompassing the transition to adulthood. The position in the household is a more appropriate way to capture the advantages and disadvantages a person faces in a particular household composition. The distinction between being an adult son or daughter or being the mother or father in a household allows the role of (mainly) the recipient and provider of resources to be taken into account. Additionally, the differentiation between childless couples, couples with one child, and those with two or more children assesses the responsibilities associated with childrearing within couples. Lone mothers and lone fathers, constituting a key group in family studies, are associated with a higher risk of poverty and a variety of health problems (Curtis and Pennock 2006; Curtis 2001; Benzeval 1998). We distinguish between (1) living alone, (2) adult son/daughter, (3) living with a partner and no children in the household, (4) living with a partner and one child, (5) living with a partner and two or more children, (6) single parent, and (7) other. The latter group includes various arrangements of shared living. As non-cohabiting relationships are not captured when focusing on household, an indicator equalling one for living apart together relationships was incorporated into the model in order to include this type of partnership. ${ }^{1}$

Available detailed information on children allows for a distinction to be made between families where parents have shared child(ren) only and stepfamilies, where at least one partner has a pre-union child, either living or not living in the household. In the remainder of the chapter, stepfamilies, patchwork families, and complex families are used synonymously. Several indicators for the existence of stepfamily context were considered, namely (1) a binary variable distinguishing whether respondents' children with a previous partner are living in the household (to avoid collinearity with single parents, this variable takes the value of one only if the respondent is living with a partner), (2) a binary variable indicating if pre-union children of the partner (i.e. respondents' stepchildren) are living in the household, (3) a binary variable indicating if the respondent has pre-union children not living in the household, and (4) a binary variable indicating if the partner has pre-union children not living in the household (i.e. respondents' stepchildren). These indicators were first analysed separately and then combined with a further dichotomous variable capturing patchwork families. The latter variable took value one if the respondent or his/her partner had pre-union children either living in or outside the household.

Various socio-demographic variables crucial for individuals' health status are included in the analyses, such as age, educational attainment, and economic situation (Ross and $\mathrm{Wu} 1995$ ). We chose education as our measure of socioeconomic status. National-specific levels are classified into four categories according to the international standard classification of education (ISCED): levels 0-2 (lower secondary

\footnotetext{
${ }^{1}$ In Austria, among persons aged $18-44$ in LAT relationships, the wish for independence and not being ready to live together were by far the reasons cited most often for not cohabiting.
} 
school or lower), 3 (upper secondary school), 4 (post-secondary non-tertiary education) and 5-6 (tertiary education). These categories represent milestones in the educational process, important in determining health and commonly used in health research (Galobardes et al. 2006). The individuals' financial situation ${ }^{2}$ is captured via the question: "Thinking about your household's total monthly income, is your household able to make ends meet (1) with great difficulty, (2) with difficulty, (3) with some difficulty, (4) fairly easily, (5) easily, or (6) very easily." This self-rated economic status is a valuable general indicator for financial capacity (Litwin and Sapir 2009). Quality of partnership measured via "How satisfied are you with your relationship with your partner/spouse?", ranging from 0 (not satisfied) to 10 (very satisfied) is another important aspect. A dichotomous variable distinguishing between satisfied (8-10) and not satisfied (0-7) was included in the analyses. ${ }^{3}$

In a first step, the household position and the health status at wave 1 are analysed from a cross-sectional perspective (see Section "Cross-Sectional Perspective: Health at Wave 1"). Descriptive statistics give an overview on what household forms Austrians aged 18-44 years live in and how they evaluate their health. Mean self-perceived health and share of persons in poor health by household position and sex provide insights into differences across groups. In multivariate analyses, self-perceived health at wave 1 is regressed on the study variables. The dependent variable, self-perceived health, was dichotomized into good versus poor health. Analyses are carried out for women and men separately in order to detect possible differences in the association between the sexes. We focus on household position and control for important background variables such as age, education, financial situation, and quality of partnership. Moreover, indicators for stepfamily context and LAT are included in the models.

In a second step (see Section "Longitudinal Perspective: Changes Over Time"), we adopt a longitudinal perspective in order to analyse changes in household position and in health over a period of four years. Descriptive results provide insights into the dynamics over time regarding health and household position. In a multivariate framework, logistic regressions depict how health at wave 2 is associated with household position and health in wave 1 and further socio-demographic characteristics. Crucial events such as the birth of a child or a change in partnership are taken into consideration. In the regression model, the independent variable is health at wave 2, measured - in line with the cross-sectional model — as a dichotomous variable ( 0 for good versus 1 for poor health). Binary logistic regression analyses with poor health at wave 2 as a dependent variable were calculated. Household position, health at wave 1 and further socio-economic determinants (both at wave 1 and wave 2) are explanatory variables, following an approach by Khalaila and Litwin (2014). By controlling for health at wave 1, we are able to capture

\footnotetext{
${ }^{2}$ As mentioned earlier, one individual per household was interviewed, thus data are independent in terms of households.

${ }^{3}$ A different grouping with 'satisfied' for 7-10 and 'not satisfied' for 0-6 leads to similar results in multivariate analyses.
} 
changes in health over time. As results for household position are similar for women and men, we run joint regressions for both sexes, controlling for sex.

Stepwise models for cross-sectional and longitudinal approaches allow insights in the mediating effects of various explanatory variables. Positive coefficients in the regression models indicate a higher risk of reporting bad health.

\section{Results}

\section{Cross-Sectional Perspective: Health at Wave 1}

In the overall sample, four in ten people were living as a couple with one or more children, one in four were (still) living in the parental home, $15 \%$ were living alone and roughly the same number were living with a partner and no children (Table 1). Four percent were single parents and the remaining 3\% reported other shared living arrangements (flat-sharing with relatives was more common than with non-relatives, like students).

A differentiation by age and gender depicts the transition to adulthood, including leaving the parental home to live alone or with a partner, and the family formation process (Table 2). Whereas below age 20 the majority was living in the parental home, this proportion decreased to one-half and two-thirds for women and men in the early twenties, and $16 \%$ and one-third, respectively, in the late twenties. From age 20 onwards, about $10-25 \%$ lived with a partner and without children. From age 25 onwards, roughly $20 \%$ shared the household with the partner and a child, and households with couples and two and more children were most frequent in the thirties and forties. Women experienced major demographic events, such as leaving the parental home, having a first, and eventually a second child, earlier than men did. Children were mainly raised in a couple context: in the age group 30-44 years, 10$13 \%$ of women were single mothers and only a minority of men were single fathers.

In young and middle adulthood, $57 \%$ perceive their health as very good, $34 \%$ as good, $8 \%$ as fair, $1 \%$ as bad, and $0.2 \%$ as very bad (Table 1$)$. Therefore, nine in ten people in this age group reported good health, the remaining $10 \%$ reported poor health. Poor health was more frequently stated by women $(12 \%)$ than by men $(7 \%)$ (Table 1). Even at this age, we find statistically significant differences in health among women and men ${ }^{4}$ (Fig. 2).

When calculating means of self-rated health measured on a five-point scale (with 1 representing very good and 5 very bad health), the variation across household position and gender becomes evident. Men and women aged 18-44 living with their parents evaluated their health best, single mothers and mothers of two and more children living with a partner worst. Although for various household arrangements differences between men and women exist, these were statistically significant only

\footnotetext{
${ }^{4}$ Confidence intervals are $[6.2 \% ; 8.4 \%]$ for men and $[10.7 \% ; 13.0 \%]$ for women.
} 
Table 1 Household position and self-perceived health of Austrian population aged 15-44

\begin{tabular}{|c|c|c|c|c|c|c|}
\hline & \multicolumn{3}{|c|}{ Percentages (weighted) } & \multicolumn{3}{|c|}{ Totals (N unweighted) } \\
\hline & $\begin{array}{l}\text { Men } \\
(\%)\end{array}$ & $\begin{array}{l}\text { Women } \\
(\%)\end{array}$ & $\begin{array}{l}\text { Total } \\
(\%)\end{array}$ & Men & Women & Total \\
\hline \multicolumn{7}{|l|}{ Household position } \\
\hline Living alone & 17 & 12 & 15 & 305 & 339 & 644 \\
\hline Son/daughter & 29 & 19 & 24 & 489 & 397 & 886 \\
\hline $\begin{array}{l}\text { Living with partner no } \\
\text { children }\end{array}$ & 12 & 14 & 13 & 334 & 446 & 829 \\
\hline $\begin{array}{l}\text { Living with partner and } \\
\text { child }\end{array}$ & 13 & 15 & 14 & 272 & 437 & 679 \\
\hline $\begin{array}{l}\text { Living with partner and } \\
\text { children }\end{array}$ & 26 & 29 & 28 & 534 & 1045 & 1560 \\
\hline Single parent & 0 & 8 & 4 & 10 & 264 & 274 \\
\hline Other & 3 & 2 & 3 & 56 & 73 & 129 \\
\hline Total & 100 & 100 & 100 & 2000 & 3001 & 5001 \\
\hline \multicolumn{7}{|l|}{ Self-perceived health } \\
\hline Very good & 57.9 & 55.3 & 56.6 & 1165 & 1664 & 2829 \\
\hline Good & 34.8 & 32.9 & 33.8 & 694 & 990 & 1684 \\
\hline Fair & 6.3 & 10.0 & 8.1 & 124 & 295 & 419 \\
\hline $\mathrm{Bad}$ & 0.8 & 1.7 & 1.2 & 14 & 45 & 59 \\
\hline Very bad & 0.2 & 0.2 & 0.2 & 3 & 7 & 10 \\
\hline Total & 100 & 100 & 100 & 2000 & 3001 & 5001 \\
\hline
\end{tabular}

Source Austrian GGS 2008/9, wave 1

for men and women living with a partner and children, while for the other groups the confidence intervals overlap (Fig. 1). An alternative way of depicting differences in health is to state the share of persons in poor health (Fig. 2). Differences by gender and household position become even more evident: 10\% among men as opposed to $15 \%$ among women living with a partner and children reported poor health. The highest share of poor health was reported by single mothers $(18 \%)$. Moreover, gender differences for those living alone and living with a partner and no children were large, although not statistically significant, as the confidence intervals overlap (Fig. 2).

Turning to the stepfamily context, mean self-perceived health was significantly worse in patchwork families (Table 3): In households where at least one partner had pre-union children either living or not living in the household, adults evaluated their own health worse than adults not living in complex families (mean self-rated health 1.67 and 1.53, respectively; the share of people in poor health was 14 and $9 \%$, respectively; confidence intervals do not overlap, see Table 3). Specification by various types of patchwork families reveals that this was especially the case for those where stepchildren were not living in the household but with the other parent. 


\begin{tabular}{|c|c|c|c|c|c|c|c|c|c|c|c|c|c|c|c|}
\hline$\stackrel{\pi}{0} \widehat{\varrho}$ & \& & 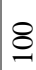 & 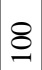 & 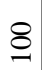 & @ & § & 8 & @ & 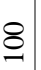 & 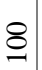 & 8 & 8 & 8 & 8 & 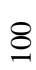 \\
\hline 离 $\widehat{Ð}$ & $m$ & $N$ & $r$ & $m$ & $N$ & - & 0 & $N$ & $\nabla$ & in & $n$ & $N$ & -1 & $\mathrm{~N}$ & $m$ \\
\hline 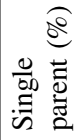 & $\nabla$ & $N$ & $\forall$ & $\nabla$ & $\stackrel{0}{0}$ & $=$ & 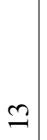 & $\infty$ & - & 0 & 0 & 0 & 0 & $\mathrm{~N}$ & 0 \\
\hline 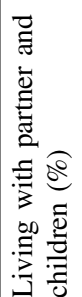 & $\stackrel{\infty}{\sim}$ & 0 & $m$ & $\cong$ & రి & 守 & o & ̀े & 0 & -1 & $a$ & 2 & $\nabla$ & $\bar{n}$ & $\stackrel{\sim}{\circ}$ \\
\hline
\end{tabular}

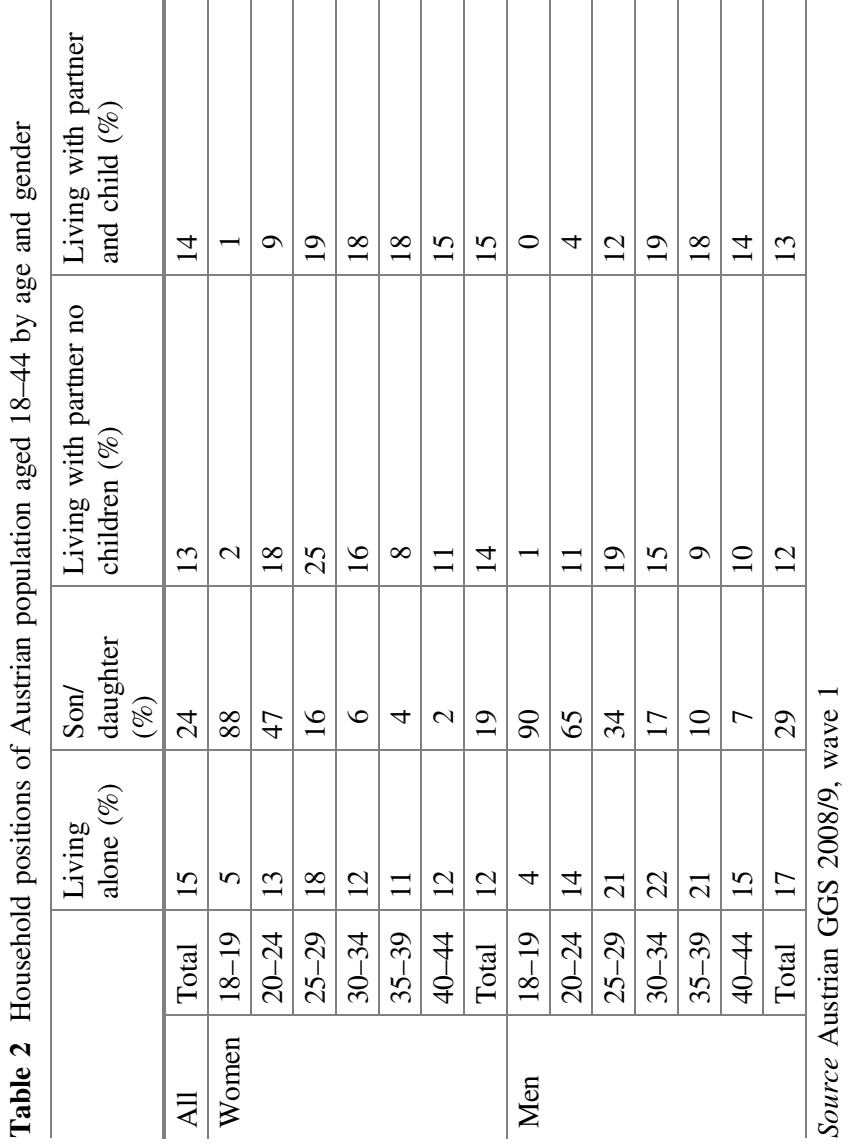




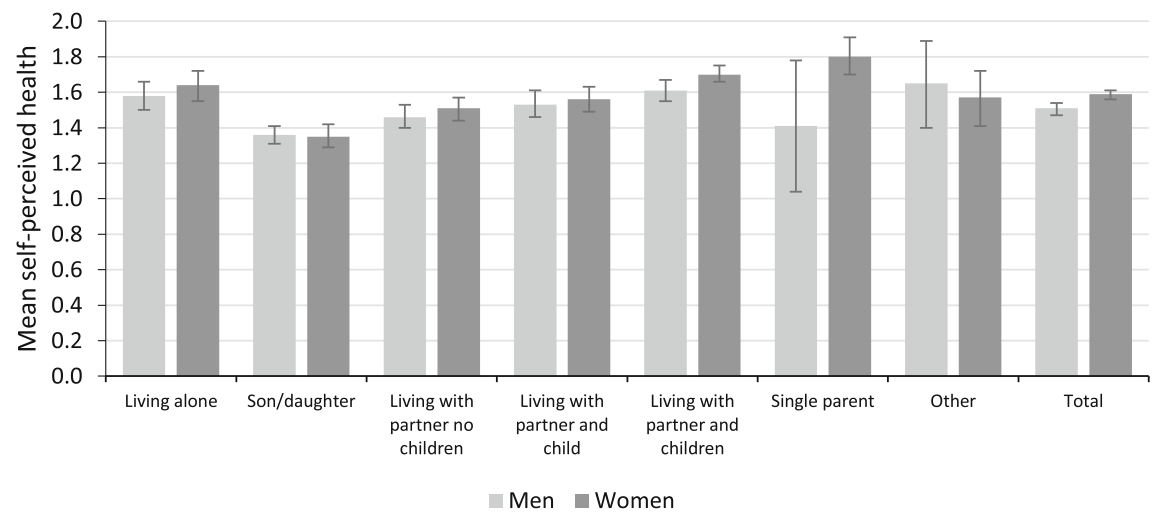

Fig. 1 Mean self-perceived health by position in household and gender. Source Austrian GGS 2008/9, wave 1

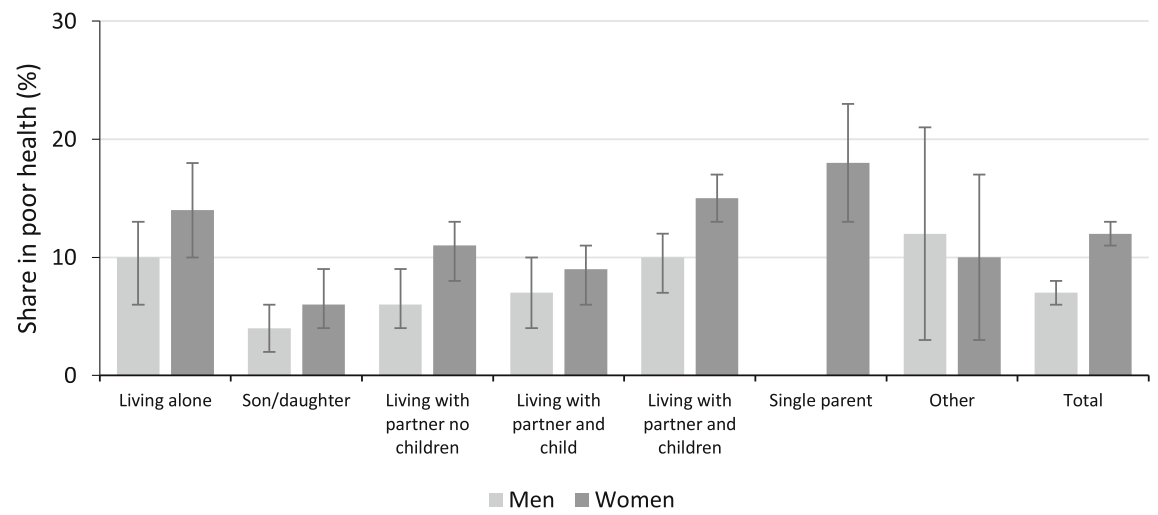

Fig. 2 Share of people in poor health by position in household and gender. Source Austrian GGS 2008/9, wave 1

A further differentiation by gender shows significant health differences for patchwork families for both women and men. ${ }^{5}$

We explored an interaction of health with education, as divorce rates are higher and available resources to handle complex family situations are fewer among less educated persons. It turned out that people with low and medium education living in stepfamilies evaluated their own health as poor (16\%) substantially more often, compared to their peers not in complex families $(10 \%)$. Moreover, highly educated

\footnotetext{
${ }^{5}$ Mean self-perceived health for women in patchwork families: 1.69 [1.60; 1.78]; for women not in patchwork families: 1.57 [1.55; 1.60]; for men in patchwork families: 1.65 [1.54; 1.76]; for men not in patchwork families: $1.49[1.46 ; 1.52]$.
} 
Table 3 Self-perceived health in stepfamily context

\begin{tabular}{|c|c|c|c|c|c|}
\hline & \multicolumn{2}{|c|}{$\begin{array}{l}\text { Self-perceived health (5-point } \\
\text { scale) }\end{array}$} & \multicolumn{2}{|c|}{ Poor self-perceived health (binary) } & \multirow[t]{2}{*}{$\mathrm{N}$} \\
\hline & Mean & $\begin{array}{l}\text { 95\% Confidence } \\
\text { interval }\end{array}$ & Mean $(\%)$ & $\begin{array}{l}\text { 95\% Confidence } \\
\text { interval }\end{array}$ & \\
\hline \multicolumn{6}{|c|}{ Children with previous partner living in the household } \\
\hline No & 1.54 & {$[1.52 ; 1.56]$} & 9 & {$[8 \% ; 10 \%]$} & 4847 \\
\hline Yes & 1.69 & {$[1.55 ; 1.82]$} & 15 & {$[9 \% ; 20 \%]$} & 154 \\
\hline \multicolumn{6}{|c|}{ Stepchildren living in the household } \\
\hline No & 1.54 & {$[1.52 ; 1.56]$} & 9 & {$[9 \% ; 10 \%]$} & 4920 \\
\hline Yes & 1.68 & {$[1.51 ; 1.86]$} & 16 & {$[8 \% ; 24 \%]$} & 81 \\
\hline \multicolumn{6}{|c|}{ Children with previous partner not living in the household } \\
\hline No & 1.54 & {$[1.52 ; 1.56]$} & 10 & {$[9 \% ; 10 \%]$} & 4884 \\
\hline Yes & 1.58 & {$[1.44 ; 1.72]$} & 11 & {$[5 \% ; 17 \%]$} & 117 \\
\hline \multicolumn{6}{|c|}{ Stepchildren not living in the household } \\
\hline No & 1.54 & {$[1.52 ; 1.56]$} & 9 & {$[9 \% ; 10 \%]$} & 4780 \\
\hline Yes & 1.75 & {$[1.64 ; 1.85]$} & 15 & [10\%; 20\%] & 221 \\
\hline \multicolumn{6}{|c|}{ Patchwork family } \\
\hline No & 1.53 & {$[1.51 ; 1.55]$} & 9 & {$[8 \% ; 10 \%]$} & 4501 \\
\hline Yes & 1.67 & {$[1.60 ; 1.74]$} & 14 & {$[11 \% ; 17 \%]$} & 500 \\
\hline
\end{tabular}

Source Austrian GGS 2008/9, wave 1

Note Due to the small number, results are not shown for women and men separately but are available upon request

people did not vary in the perception of their own health whether they were living in patchwork families or not (Fig. 3).

Next, multivariate models examine the association between household position and health. In a stepwise procedure, age, educational level, stepfamily context, economic constraints (e.g. having to make ends meet), existence of LAT relationship, and partnership quality were included. Individuals living with a partner and one child in the household are the reference group. In a basic model including only household position, women living alone, women living with a partner and two or more children, and single mothers statistically significantly reported poor health more often, whereas men living in the parental home did so less often (Table 4, Models 1). As expected, age and education are strongly associated with self-perceived health (Table 4, Models 2): Poor health was more often reported with increasing age. Results for education are less straightforward. With upper secondary school as the reference group, the association between women's health and education is evident; i.e. health outcomes are poor especially for those with low levels of education. In contrast, more highly educated men report poor health significantly less often. In other words, education and health are positively associated across gender, although less educated women report significantly lower health compared to their more highly educated peers, but it is the men with higher education who report more positive health outcomes. When controlling for age, the 


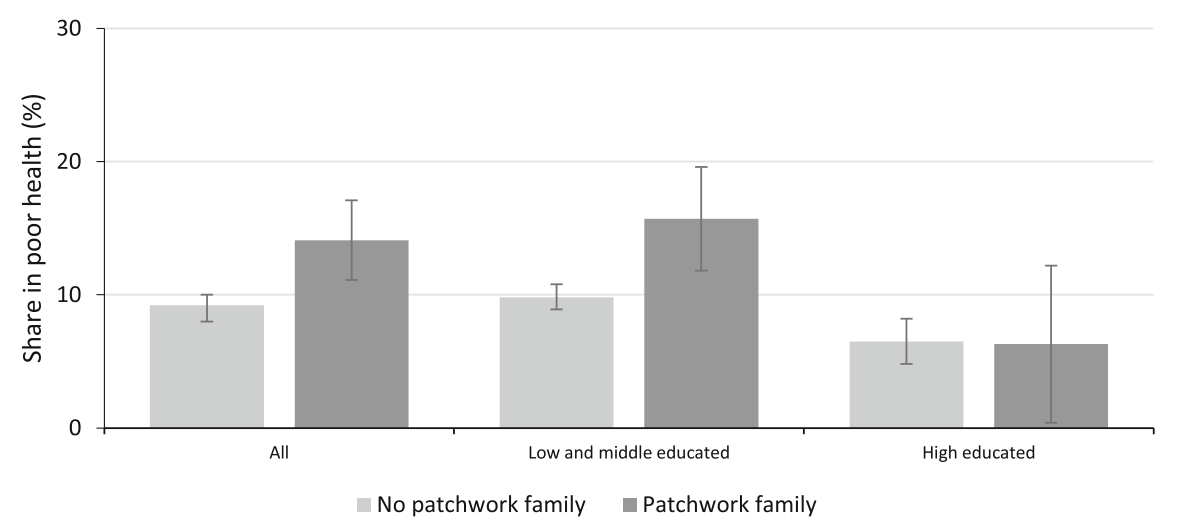

Fig. 3 Share of people in poor health by patchwork family status and education. Source Austrian GGS 2008/9, wave 1

estimated coefficient for women living in the parental home becomes positive and statistically significant. This indicates that the originally good self-perceived health of adult women living as daughters in the parental home is due to their young age. The same holds true for women and men living in shared households with relatives or non-relatives, but not parents, children, or partners. On the opposite side, the significant negative coefficient for sons becomes non-significant, showing again that the good health of men living in the parental home is mainly due to age and educational differences.

Furthermore, we find that women living in patchwork families more often reported poor health than those who are not (Table 4, Models 3). For men, the estimated coefficient is also positive, but lacks statistical significance. When introducing LAT partnership, the estimated coefficient is negative both for women and men, but statistically significant only for men (Table 4, Models 4). This indicates that men who have a romantic relationship, but who do not live together with that person, report good health. Moreover, people having an LAT partnership report positively on their health. We also find that economic constraints are important: the easier young and middle-aged adults can make ends meet, the better their health (Table 4, Models 5). In Model 5 we included the variable "making ends meet" to account for financial constraints. This operation reduces the size and significance of the status "being a single mother", showing that part of their less favourable health is due to financial constraints. Moreover, the smaller and less significant coefficient for education in Model 5 compared to Model 4 shows that educational level correlates with one's financial situation. Similarly, the coefficient for patchwork families becomes smaller in size and statistical significance, indicating correlations between stepfamily context and economic constraints. Finally, we only consider individuals with a partner (either cohabiting or LAT) and find that men and women who are less satisfied with their partnership more often report poor health (Table 4, Models 6). 


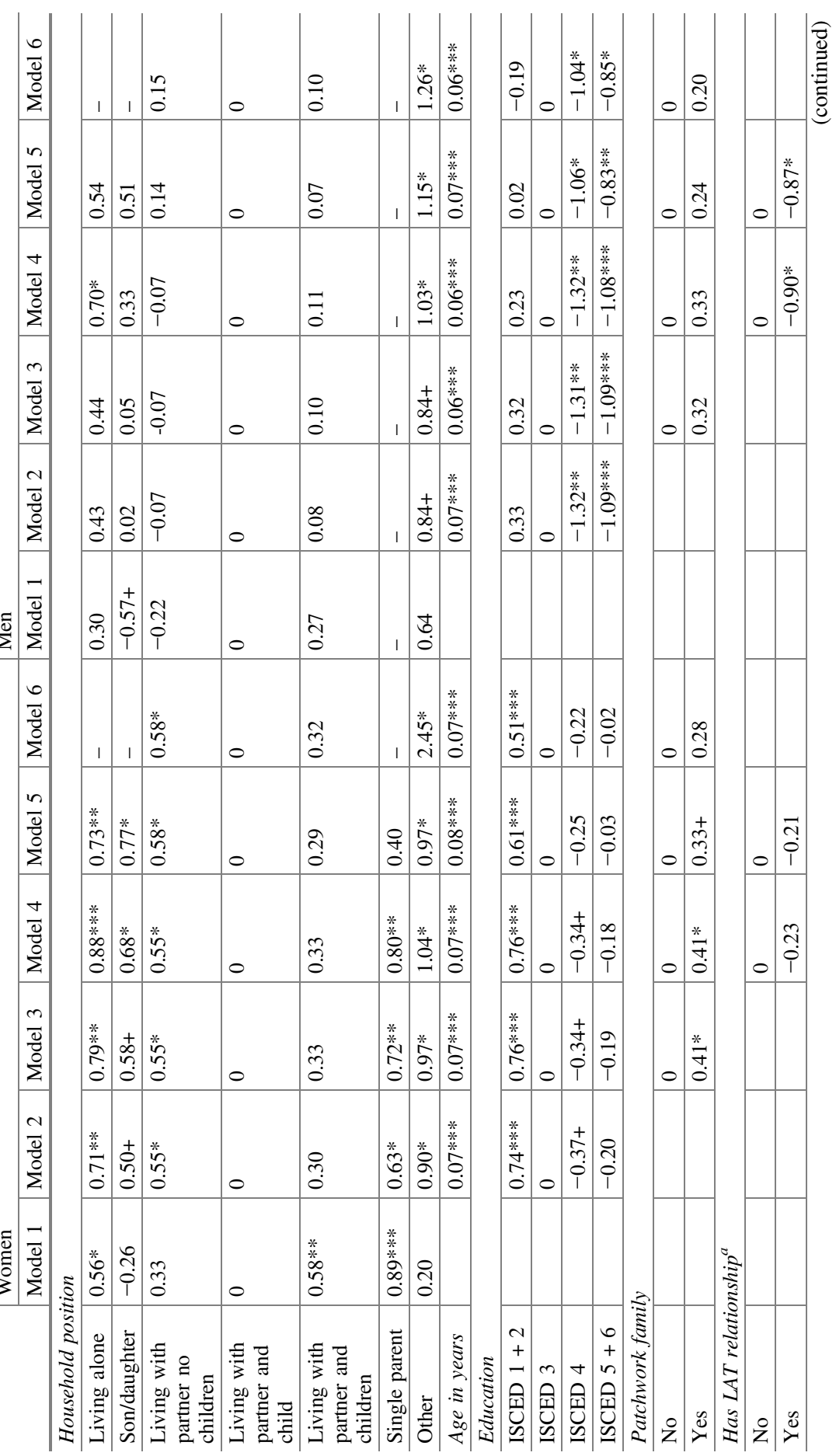




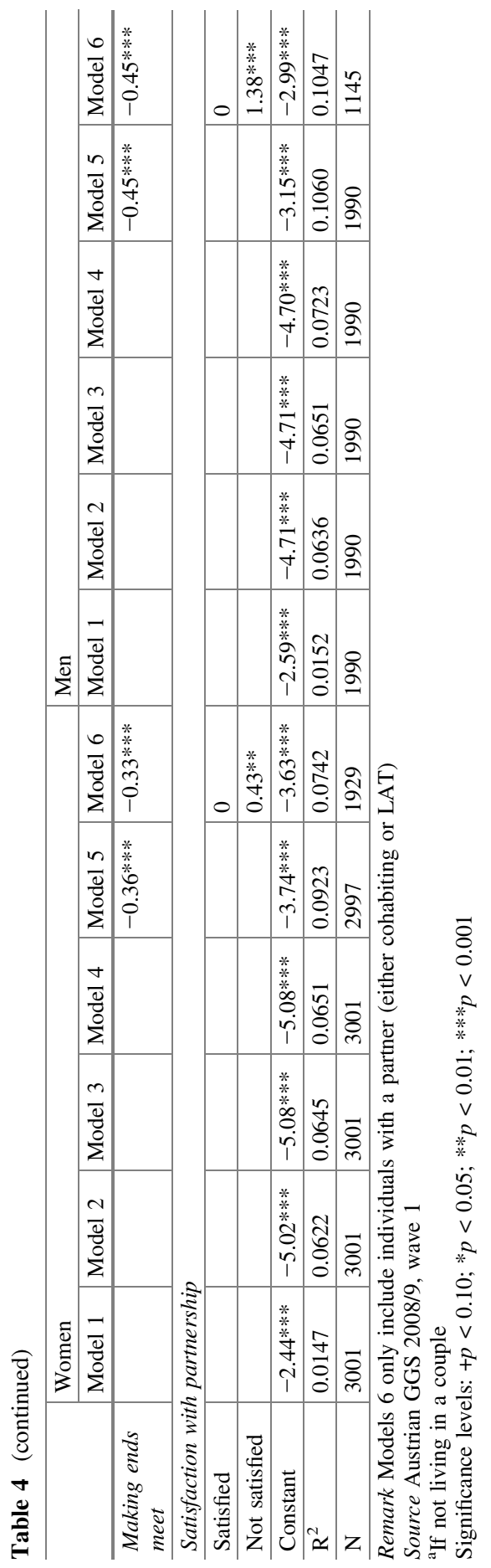


Our multivariate models show that health outcomes are related to different living arrangements for women and men. Women living with a partner and one or more children in the household reported better health than their peers in other household positions. Those women living with a partner and two or more children evaluated their health in a similar way as those cohabiting with one child and a partner. This is in contrast to women living alone, in the parental household, with a partner but no children, single mothers, as well as women in shared households who reported bad health significantly more often than women living with a partner and one child. Among men, those living alone and in shared households reported poor health more often. Apart from significant associations with age, education, financial constraints, and partnership quality for both sexes, patchwork context further determines the subjective health of young and middle aged women negatively, whereas LAT relationships are associated with better health among men. The fact that the coefficient for single mothers changes in the stepwise setup of the model when including LAT and making ends meet indicates a complex interaction of these dimensions and mediating effects. In summary, our results show that socio-economic factors and health characteristics generate household contexts that mediate the way household structure and self-rated health in young and middle adulthood plays out.

\section{Longitudinal Perspective: Changes Over Time}

In this section, we focus on the longitudinal sample. As mentioned earlier, panel attrition in the Austrian GGS was comparably low (22\%). Of the 5001 wave 1 respondents interviewed in 2008/9, a total of 3908 individuals participated in wave 2 four years later (2012/13). About eight in ten reported good health at both interviews, for roughly one in ten health had deteriorated from good to poor, whereas for $4 \%$ health improved from poor to good. A small, but not negligible group (5\%) declared poor health at both interview time points (Table 5). Against the argument that health outcomes vary by gender in late adulthood and old age, our data show apparent gender differences even in early and middle adulthood: Whereas $85 \%$ of men reported good health in both waves, this proportion is significantly smaller among women $(80 \%)$. In other words, two in ten women reported fair or bad health at least once when interviewed four years apart. As expected, changes in health vary substantially by age: Whereas below age 20 , nine in ten reported good health at both waves, this was the case for roughly seven in ten in their early forties (Table 5). The longitudinal approach supports our cross-sectional evidence (Fig. 3) that poor health in complex families mainly involves low educated persons, whereas their highly educated peers do not report worse health (Table 5).

Differentiating among seven different household types would have made the interpretation of changes in household position very complex (49 possible combinations). We thus distinguished first between those who had no change and those who had one change in the household position between waves: Roughly two thirds 
Table 5 Change in health between wave 1 and wave 2 by gender, age, and stepfamily context

\begin{tabular}{l|l|l|l|l|l}
\hline & $\begin{array}{l}\text { Good } \rightarrow \text { good } \\
(\%)\end{array}$ & $\begin{array}{l}\text { Poor } \rightarrow \text { good } \\
(\%)\end{array}$ & $\begin{array}{l}\text { Good } \rightarrow \text { poor } \\
(\%)\end{array}$ & $\begin{array}{l}\text { Poor } \rightarrow \text { poor } \\
(\%)\end{array}$ & $\begin{array}{l}\text { Total } \\
(\%)\end{array}$ \\
\hline Gender & \multicolumn{5}{|l}{} \\
\hline Men & 85 & 3 & 8 & 4 & 100 \\
\hline Women & 80 & 5 & 9 & 6 & 100 \\
\hline Total & 83 & 4 & 5 & 100 \\
\hline Age & 8 & 1 & 100 \\
\hline $18-19$ & 91 & 3 & 5 & 2 & 100 \\
\hline $20-24$ & 90 & 4 & 2 & 100 \\
\hline $25-29$ & 88 & 3 & 6 & 4 & 100 \\
\hline $30-34$ & 84 & 4 & 8 & 6 & 100 \\
\hline $35-39$ & 79 & 4 & 11 & 9 & 100 \\
\hline $40-44$ & 73 & 4 & 11 &
\end{tabular}

Patchwork in wave 1 and low or middle level of education

\begin{tabular}{l|l|l|l|l|l}
\hline No & 83 & 4 & 8 & 5 & 100 \\
\hline Yes & 75 & 6 & 10 & 9 & 100 \\
\hline
\end{tabular}

Patchwork in wave 1 and high level of education

\begin{tabular}{l|l|l|l|l|l}
\hline No & 86 & 5 & 8 & 2 & 100 \\
\hline Yes & 84 & 5 & 7 & 4 & 100 \\
\hline
\end{tabular}

Source Austrian GGS 2008/9 and 2012/13, wave 1 and wave 2

did not change their household position and about one third did over the four-year period. Part of these changes were from "childless couple" to "couple with child (ren)" or from "couple with one child" to "couple with two and more children". In addition, in some households an adult child left the parental home. We find that $12 \%$ had changes due (mainly) to the arrival of a newborn, whereas $24 \%$ had a change in the household position due to other reasons, including the formation of a new partnership, moving together with a partner, separation, and divorce (Fig. 4). Changes in household position were frequent for those initially living in the parental home and living alone-and therein more often among women than men. Also shared living arrangements with friends, students, or relatives (e.g. siblings) turned out to be more transitory living arrangements. The observation that changes in the household position differed over the life course is reflected in the mean age across groups: People without change in household position had mean age of 34 years, those reporting a change were either substantially younger, 28 years on average, or substantially older (42 years) if experiencing empty nest (Table 6). People who had a newborn between the two waves were about 30 years at wave 1 .

The majority of the respondents reported good health at both interviews, and this was more often the case if a change in the household position took place $(86 \%$, compared to $81 \%$ of those remaining in the same household position). The share of people who recently transitioned to parenthood and who were in good health at both 


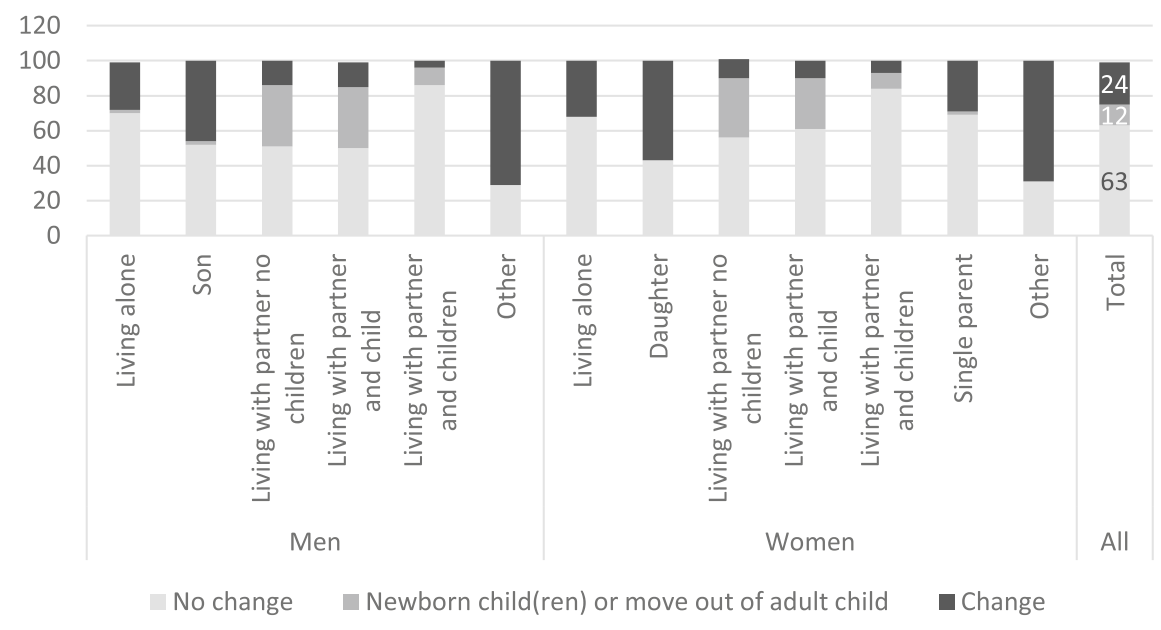

Fig. 4 Change in the household position. Source Austrian GGS 2008/9 and 2012/13, wave 1 and wave 2. Remark 1: Single fathers are omitted due to the small number remaining in wave 2. Remark 2: In the group "Newborn child(ren) or move out of adult child", the majority (92\%) comprises $92 \%$ arrival of a newborn, a minority (8\%) move out of adult child(ren)

Table 6 Change in the household position and change in health between wave 1 and wave 2

\begin{tabular}{l|l|l|l|l|l}
\hline & $\begin{array}{l}\text { No } \\
\text { change }\end{array}$ & Change & $\begin{array}{l}\text { Newborn child } \\
\text { (ren) }\end{array}$ & $\begin{array}{l}\text { Adult child(ren) } \\
\text { moved out }\end{array}$ & Total \\
\hline Good $\rightarrow$ good & $81 \%$ & $86 \%$ & $89 \%$ & $60 \%$ & $83 \%$ \\
\hline Poor $\rightarrow$ good & $5 \%$ & $4 \%$ & $2 \%$ & $8 \%$ & $4 \%$ \\
\hline Good $\rightarrow$ poor & $9 \%$ & $7 \%$ & $7 \%$ & $8 \%$ & $8 \%$ \\
\hline Poor $\rightarrow$ poor & $6 \%$ & $3 \%$ & $2 \%$ & $23 \%$ & $5 \%$ \\
\hline Total & $100 \%$ & $100 \%$ & $100 \%$ & $100 \%$ & $100 \%$ \\
\hline $\begin{array}{l}\text { Mean age at } \\
\text { wave 1 }\end{array}$ & 34 & 28 & 30 & 42 & 32 \\
\hline $\mathrm{N}$ & 2507 & 849 & 513 & 39 & 3908 \\
\hline
\end{tabular}

Source Austrian GGS 2008/9 and 2012/13, wave 1 and wave 2

waves even amounted to $89 \%$ (Table 6). The small group of respondents where an adult child had left the parental home between waves had worst self-perceived health, as only six out of ten reported good health both times. As mean age substantially varies within groups, with changes in household position and transition to parenthood being more frequent in young adulthood, age is an important determinant for changes in health over time. 


\section{Change in Health If No Change in the Household Position}

Changes in the partnership do not necessarily change a person's household position, but can still affect individual health outcomes: $6 \%$ of respondents were living as a couple but with different partners at both waves, 5\% reported an LAT partner in wave 1 , but not so in wave 2 , and $9 \%$ had no LAT partner at wave 1 but did so at wave 2 . The remaining persons either had the same partner $(64 \%)$ or no partner $(16 \%)$ in both waves. This distinction was taken into account.

Model 1 that regresses effects of household position on health in wave 2 suggests that persons living continuously alone and especially single parents reported poor health at wave 2 more often, whereas living in the parental home was associated with better health (Table 7, Model 1). As only a few single fathers remained in the longitudinal sample, the single parents are mainly single mothers. Model 2 introduces health at wave 1, which is crucial for health reported four years later: The estimated coefficient is large in size and highly statistically significant, showing that persons who reported bad health at wave 1 , also did so substantially more often at wave 2 (Table 7, Model 2). Next, parents in stepfamily context at wave 1 reported poor health at wave 2 more often, even after controlling for health at baseline (Table 7, Model 3).

In Models 4 and 5 we included the socio-demographic variables of sex, age, and education. Women and men did not significantly differ in self-perceived health at wave 2 , once the initial health status at wave 1 was controlled for, whereas age and education have further explanatory power (Table 7, Models 4 and 5). Having no partner at all in both waves, breaking up a LAT partnership and a partner change (either cohabiting or non-cohabiting) are also associated with bad health (Table 7, Model 6). Not only the financial situation at wave 2, but also economic constraints at wave 1 (still) are related with poor health at wave 2 (Table 7, Model 7). As in the cross-sectional model, current partnership quality is related with current self-perceived health (Table 7, Model 8). In the final model, poor health at wave 1, age, education, economic constraints at both observations, having no partner (not even a non-co-residing one) at both interview times, breaking up with a partner as well as partnership quality at wave 2 are all associated with bad health at wave 2 . We might conclude that from a longitudinal perspective the association with age, education, economic constraints, and having no partner even got stronger. Once these determinants are taken into account, the only household position significantly associated with health is living in the parental home, whereas stepfamily context no longer has explanatory power. The stepwise model specification shows that especially educational differences and economic constraints associated with certain household positions and with stepfamilies are mediating factors for poor health.

In young and middle adulthood, a substantial number of people experienced first or repeated parenthood over a period of four years, whereas some early parents witnessed empty nests as their adult children moved out. People who became parents evaluated their health best: Nine in ten were in good health at both waves (Table 6). Parents whose children moved out reported poor health more often compared with the parents of newborn children (Table 6). In multivariate analyses, 


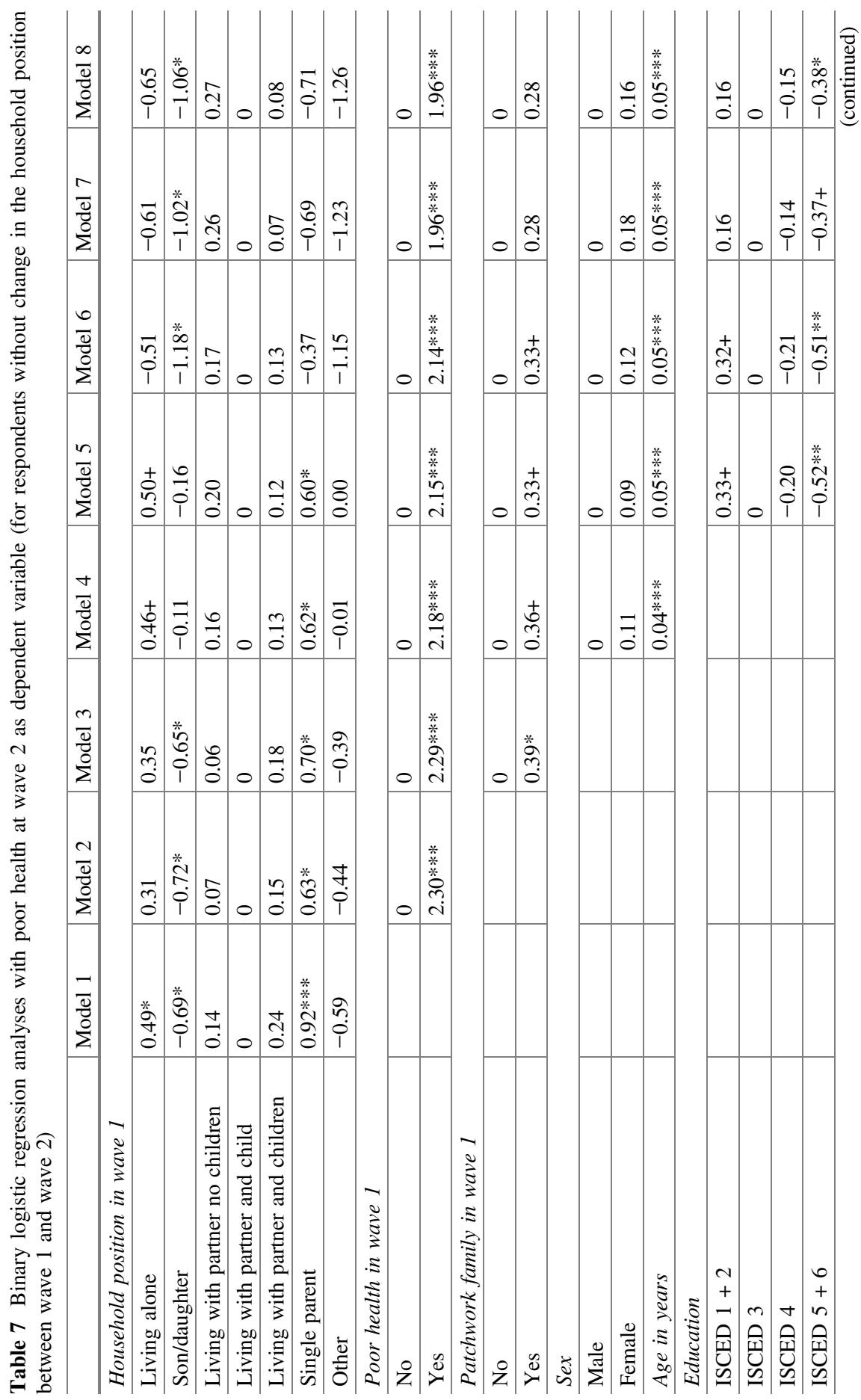




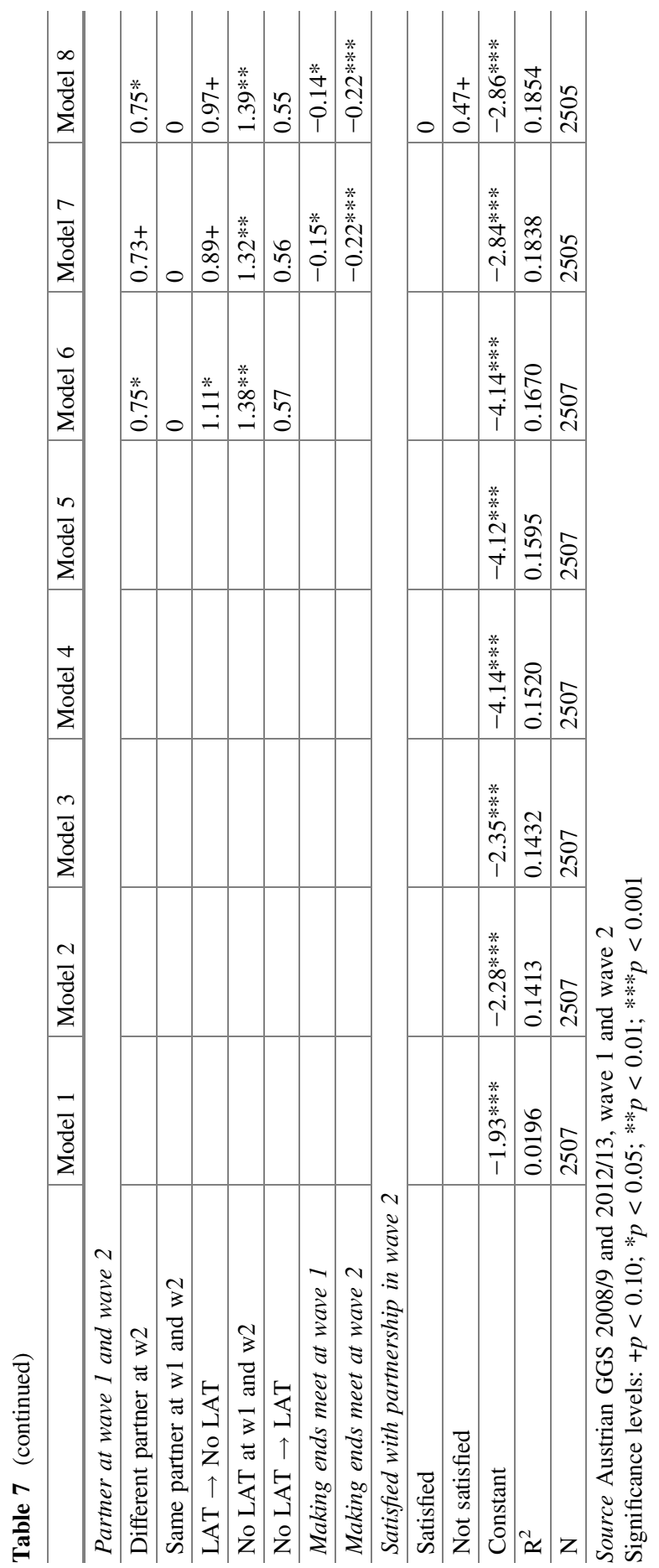


health at wave 1 was the main explanatory factor for health at wave 2 . Moreover, low education was associated with poor health, further indicating increasing educational differences over time (results available on request). Stepwise multivariate models showed that health at wave 1 and age were the main mediating factor for poor health of parents experiencing an empty nest.

\section{Change in Health If Household Position Changes}

We now turn to the analyses of changes in health if changes in the household position occurred. This dynamic group encompasses rather young adults, with a mean age of 28 at wave 1 . As changes across the detailed household positions become too complex, we distinguish between living as a couple and not living as a couple: One in two people moved together with a partner in a joint household (Table 8). About one in four separated (were living with a partner at wave 1, but not at wave 2), and another one in four changed within the non-couple-context, including living in the parental home, in a single household or in a shared household with non-relatives. Moving together with a partner and changing non-couple-living arrangement was more common among younger adults (mean age 27 and 25 years), persons involved in separations were significantly older (34 years) (Table 8 ).

In multivariate analyses, people moving together with a partner are the reference group. In the basic model, separation is associated with poor health at wave 2 (Table 9, Model 1). As expected, self-perceived health at wave 1 is important (Table 9, Model 2). Patchwork family at wave 1 and gender have no explanatory power, whereas age is an important determinant for health at wave 2 (Table 9, Models 3-5). Although the estimated coefficients for education fail statistical significance, they do point in the expected direction, with better health among higher educated (Table 9, Model 6). With the inclusion of age, the estimated coefficient for "couple $\rightarrow$ no couple" decreases in size and statistical significance (from $0.83 * *$ to $0.51+)$. With the further inclusion of education, it becomes insignificant (0.46). First bivariate analyses mentioned above showed substantial differences in mean ages across groups, and multivariate regressions confirmed that age is an important mediator for the relation between household dynamics and health. As adults were

Table 8 Distribution and mean age by couple context

\begin{tabular}{l|l|l}
\hline & Mean age \\
\hline Couple $\rightarrow$ couple & $4 \%$ & 35 \\
\hline No couple $\rightarrow$ couple & $51 \%$ & 27 \\
\hline Couple $\rightarrow$ no couple & $22 \%$ & 34 \\
\hline No couple $\rightarrow$ no couple & $23 \%$ & 25 \\
\hline Total & $100 \%$ & 28 \\
\hline
\end{tabular}

Source Austrian GGS 2008/9 and 2012/13, wave 1 and wave 2; $\mathrm{N}=849$ respondents with a change in household position between wave 1 and wave 2 


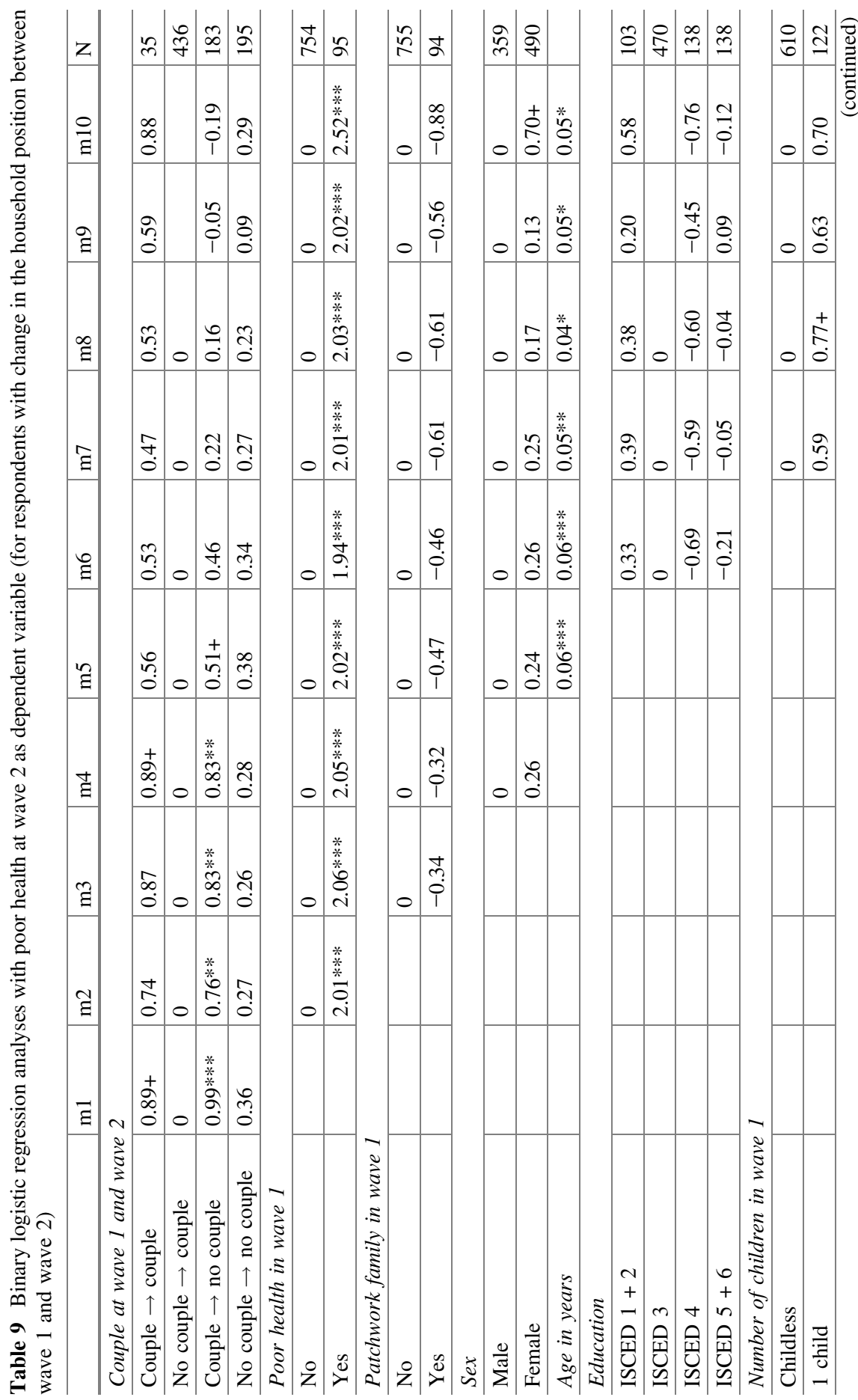




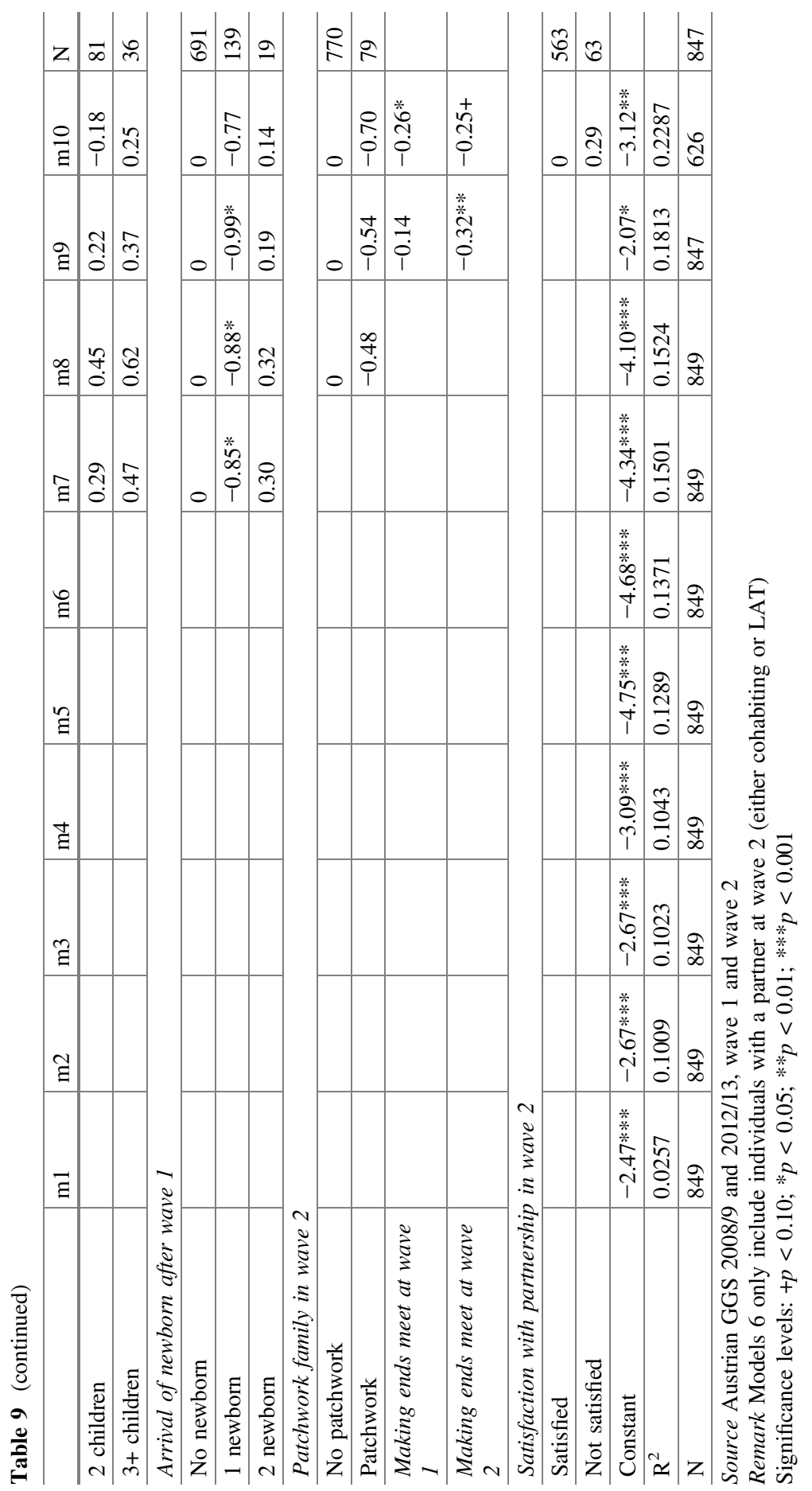


on average in their late twenties when moving together with a partner and in their mid-thirties when separating from their partner, some of the health differences are explained by age differences.

In the final model, poor health at wave 1, age, and financial constraints at wave 2 are significantly related with poor health at wave 2 , the arrival of a newborn is associated with good health (Table 9, Model 9). The stepwise model setup allows insights for the association between explanatory variables: As the estimated coefficient for separation becomes almost zero when including economic constraints (Table 9, Models 8 and 9), we might conclude that financial problems after separation are coupled with poor health. Regarding the birth of a newborn: The estimated coefficient for the small group of persons having two newborn children within a period of four years is positive. Although not statistically significant, this is in sharp contrast to the large and highly significant coefficient for the arrival of one newborn child, thus indicating the stress of having two children within a short period of time. Finally, when including individuals with a partner at wave 2 (either cohabiting or LAT), the estimated coefficients for current satisfaction with partnership lie in the expected direction, but are not statistically significant.

We carried out all analyses for ages 25-44 only, thus excluding young adults aged 18-24. As expected, the overall share of persons living with their parents decreased from 24 to $11 \%$ and mean self-perceived health became worse (52\% rated own health as very good, as compared to $57 \%$ for ages 18-44). When excluding young adults - who most often lived in the parental home, especially mean self-perceived health among those living with parents decreased. Nevertheless, in multivariate regressions, the estimated coefficients for household position and control variables are in line with results derived for the age group 1845 , with minor deviations in size and statistical significance.

\section{Discussion}

Despite extensive evidence of the broad-ranging impact of single parenthood and family disruption, few studies have examined the relationship between family composition and health, and none have examined the full range of structural and social correlates across two parent families, stepfamilies, and single mother families. Yet, causation has often been a problem given that the majority of available data sets were cross-sectional. There are a few exceptions, including longitudinal studies that find selection to operate alongside divorce effects (Hope et al. 1999; Mastekaasa 1997; Davies et al. 1997). Whether causation or selection are the drivers for the association between health and living conditions can be disentangled only with longitudinal studies capturing these dimensions from youth and early adulthood onwards. The aim of this study has therefore been to provide cross-sectional and longitudinal evidence toward differentiating these effects. According to previous literature and theoretical frameworks, we formulated various expectations on the associations between household position and health. 
In line with our first expectation, we find a clear association between living together with a partner as compared to not living in a couple context. Individuals living alone and single parents reported bad health significantly more often than those living with a partner and one child. Differences remain, even after controlling for socio-economic conditions. Living together with a partner in young and middle adulthood corresponds to the 'normative life course' and is positively related with self-perceived health.

A second important finding is that - if not cohabiting with a partner-having a living apart together partner is positively related with health among men. Thus, it is not only marital status and cohabitation which are associated with health (Horwitz and White 1998; Lillard and Panis 1996), but an LAT partnership was also related with it, especially among men.

Numerous studies have examined mortality as well as health and marital status (Lillard and Panis 1996; Lillard and Waite 1995; Bardage et al. 2005), concentrating on old age, but our study reveals insights for an association between partner status and health already much earlier in life. We might conclude that no, or missed, transitions might be against the norm and associated with poor health. Our results on poor health in non-partnership are to some extent contrary to the well-known idea of the 'de-institutionalization' of the life course that the social and temporal organization of the life course becomes less guided by normative, legal or organizational rules (Elzinga and Liefbroer 2007).

Further evidence in the realm of partnership concerns the quality of the relationship, confirming earlier research (Umberson et al. 2006; Miller et al. 2013). As expected, partnership quality is associated with health, underlining the relevance of psychological well-being for self-perceived health. In addition, the size of the estimated coefficient indicates that these are important determinants for self-perceived health in young and middle adulthood.

Our study provides important insights into health in stepfamilies in the European context. According to research results in the US (Heard et al. 2008; Turney and Carlson 2011), our expectation was that individuals living in patchwork families would report poor health more often. Our results indicate that Austrian women living in complex families rated their health as poor more often than did women cohabiting with a child or children and partner and no pre-union children, either their own or from the partner. People living in patchwork families may experience stress as they are raising their offspring. Stepfamily context and childrearing across households may create ambiguous family boundaries, increase conflict in couple relationships, and diminish the quality and quantity of parental investment in children, all of which may lead to impaired mental health (Boss 1980; Cherlin and Furstenberg 1994; Turney and Carlson 2011). As results are not significant for Austrian men living in a stepfamily context, we find evidence for gender differences with regard to complex families.

The gender gap in life expectancy is a well-known fact in demography, with female life expectancy exceeding that of males (Waldron 2000; Luy and Gast 2014; Caselli et al. 2014). Research on gender differences in mortality and morbidity has mainly focused on older people (Bardage et al. 2005), but our study provides 
evidence that women evaluate their health worse than men already in young and middle adulthood. In line with previous literature, age and education are positively associated with subjective well-being (Bardage et al. 2005). Moreover, educational and gender specific differences become evident, stemming from both cross-sectional and longitudinal approaches: Poor health in complex families is observed among people with less education, whereas highly educated people in a stepfamily context do not report worse health.

Age and education turned out to be crucial mediators for poor health. For example, we anticipated negative health outcome for mothers of two or more children. In fact, this group reported poor health more often than women with their partner and one child only. But when controlling for age and education, the effect for mothers of two and more children became insignificant. Controlling for socio-economic factors also appreciably reduced the effect for single mothers. The latter is consistent with earlier findings from a study in the US (McLanahan and Sandefur 1994), which asserts that single parent families are not inherently problematic but rather are affected by deprivation in economic, parental, and community resources. The deficits for single mothers are reduced when making ends meet is controlled for. Having a higher education and fewer economic constraints contribute to better health assessments. This suggests that structural disadvantages can help to create health disadvantages for people through the family environment in which they live. Single parents and stepfamilies are not "inherently problematic, but are likely to occur in concert with demographic, economic, psychosocial, and behavioural risk factors" which more directly influence health (Heard et al. 2008, p. 775f).

In the longitudinal approach, the effect of new parenthood turned out to be strong. Our expectations that the arrival of a newborn child has a positive effect on health was confirmed. Nevertheless, the birth of two children within a rather short period of four years tended to be associated with poor health, indicating stressful situations for the new parents. According to existing research, our expectation was that separation harms subjective health in the short- and medium term, which is expressed by lower self-assessed health after separation. Looking into the longitudinal analyses we observe that individuals who changed from a couple-context to a non-couple context within four years reported poor health more often at the second point in time compared to those who changed from a non-couple to a couple-context. But this difference vanished when controlling for age, education, and existence of LAT partnership, indicating at a complex relationship between different life domains and age. A further important result is that the association with age, education, economic constraints, and having no partner became even stronger from a longitudinal perspective. These results confirm our cross-sectional findings and reflect that transitions against the norm (e.g. union dissolution and separation) generate lasting negative health effects. It also implies that such transitions underlie age and socio-structural mechanisms such as education and economic status that are well-known determinants of health (Avendano et al. 2009; Stutzer and Frey 2010).

Some limitations of this study should be mentioned. First, this study is limited to self-perceived health and we are not able to disentangle the various dimensions of 
self-perceived health in the current study with the data at hand. Self-rated health is, however, the most widely regarded valid and reliable indicator of health status, although we acknowledge the meaning of self-rated health to differ between individuals (Schüz et al. 2011). Self-reported health is a multidimensional and multifaceted construct (Liang 1986), including-among others-functional status, behavioural factors, and interpersonal resources. It has been suggested that psychological factors in particular can be crucial for self-perceived health. Experiencing depression is a key predictor of self-rated health besides physical symptoms (Schneider et al. 2004; Schüz et al. 2011). As our target population are people in young and middle adulthood, physical impairments might be less important and mental problems might determine to a larger extent the self-perception of health. Scholars have shown that self-assessments of teen and adolescence health are more likely to reflect overall functioning and life difficulties (e.g. participation in sports, school achievement, relations with friends, high Body Mass Index (BMI), depressed mood) than physical symptoms (Mechanic and Hansell 1987; Vingilis et al. 1998). Further evidence on longitudinal data suggests that health ratings seem to become less dependent on one's social well-being and more determined by current health characteristics and behaviours, as individuals transit from adolescence to young adulthood (Heard et al. 2008). Studies have shown the importance of psychological well-being and health behaviours for adolescent self-assessments of health, highlighting the importance of self-esteem, high BMI, and participation in sports or other forms of exercise (Mechanic and Hansell 1987; Vingilis et al. 1998; Heard et al. 2008).

Second, our longitudinal analyses are based on two observations four years apart. It is possible that some respondents might have experienced further changes between waves which are not captured in the current study. Third, the longitudinal sample is slightly biased towards healthy respondents, as dropout was higher among persons reporting poor health at wave 1 (Buber-Ennser 2014).

Despite these limitations, the results have a number of implications for our understanding of differences in health outcomes, and household position and parenthood. First, in line with the literature on the relationship between healthy behaviour and its protective effect on health and mortality (Berkman and Glass 2000; Gorman and Sivaganesan 2007), individuals' social ties are apparently an important determinant. Our findings confirm the argument that marriage provides social support (Lillard and Panis 1996), comprising emotional support (family integration, stress reduction) and instrumental support (provision of care), which are associated with reduced health impairments. Second, apart from knowledge on marriage and cohabitation - especially at old age - (Scafato et al. 2008), the current study provides evidence that social ties and support gained in new forms of unions such as living apart together are also associated with better subjective health. Third, most studies examining the association between marital status and health and mortality focus on the elderly population, whereas this study provides insights for young and middle adulthood. It is important to consider family and household structure during early and middle adulthood, as it may initiate a health trajectory that can either protect or harm health across the life course (Wadsworth 1997). 
Overall, we show that if perceived health varies by household position and parental status, it also varies within household position category according to individuals' living arrangements and actual or missed transitions, such as the moving out of the parental home or the arrival of a newborn. Our findings are conservative, as we are examining a context in which parenting and the division of paid labour and domestic and care work are highly gendered. In gender unequal contexts, social inequalities by education, gender, and entry into various living arrangements may play a major role in who is able to maintain good health and who is not.

Acknowledgements The Austrian GGS was financed by the Federal Ministry of Economy, Family and Youth, the Federal Ministry of Science and Research and the Federal Ministry of Labour, Social Affairs and Consumer Protection. We thank Christian Wegner-Siegmundt, Gabriele Doblhammer, and Jordi Gumà for valuable comments and Werner Richter, Ian Copestake and Renee Lueskow for language editing.

\section{References}

Aassve, A., Goisis, A., \& Sironi, M. (2012). Happiness and childbearing across Europe. Social Indicators Research, 108(1), 65-86. https://doi.org/10.1007/s11205-011-9866-x.

Amato, P. R. (2000). The consequences of divorce for adults and children. Journal of Marriage and Family, 62, 1269-1287.

Amato, P. R. (2010). Research on divorce: Continuing trends and new developments. Journal of Marriage and Family, 72(3), 650-666. https://doi.org/10.1111/j.1741-3737.2010.00723.x.

Amato, P. R., \& Hohmann-Marriott, B. (2007). A comparison of high- and low-distress marriages that end in divorce. Journal of Marriage and Family, 69(3), 621-638. https://doi.org/10.2307/ 4622471.

Aseltine, R. H., Jr., \& Kessler, R. C. (1993). Marital disruption and depression in a community sample. Journal of Health and Social Behavior, 34(3), 237-251. https://doi.org/10.2307/ 2137205.

Avendano, M., Jürges, H., \& Mackenbach, J. P. (2009). Educational level and changes in health across Europe: Longitudinal results from SHARE. Journal of European Social Policy, 19(4), 301-316. https://doi.org/10.1177/1350506809341512.

Ball, K., Burton, N. W., \& Brown, W. J. (2009). A prospective study of overweight, physical activity, and depressive symptoms in young women. Obesity, 17(1), 66-71. https://doi.org/10. 1038/oby.2008.497.

Baranowska, A., \& Matysiak, A. (2011). Does parenthood increase happiness? Evidence for Poland. Vienna Yearbook of Population Research, 9, 307-325. https://doi.org/10.1553/ populationyearbook2011s307.

Bardage, C., Pluijm, S. M. F., Pedersen, N., Deeg, D. J. H., Jylhä, M., Noale, M., et al. (2005). Self-rated health among older adults: A cross-national comparison. European Journal of Ageing, 2(2), 149-158. https://doi.org/10.1007/s10433-005-0032-7.

Beaujouan, E. (2011). Second-union fertility in France: Partners' age and other factors. Population-E, 66(2), 239-274.

Beaujouan, E., \& Bhrolcháin, M. N. (2011). Cohabitation and marriage in Britain since the 1970s. Population Trends, 145(3), 35-39. 
Beaujouan, E., \& Solaz, A. (2013). Racing againt the biological clock? Childbearing and sterility among men and women in second unions. European Journal of Population, 29(1), 39-67. https://doi.org/10.1007/s10680-012-9271-4.

Benzeval, M. (1998). The self-reported health status of lone parents. Social Science and Medicine, 46(10), 1337-1353. https://doi.org/10.1016/S0277-9536(97)10083-1.

Berghammer, C. (2014). The return of the male breadwinner model? Educational effects on parents' work arrangements in Austria, 1980-2009. Work, Employment \& Society, 28(4), 611623. https://doi.org/10.1177/0950017013500115.

Berkman, L. F., \& Glass, T. (2000). Social integration, social networks, social support, and health. In L. F. Berkman \& I. Kawachi (Eds.), Social epidemiology (pp. 137-173). Oxford, New York: Oxford University Press.

Bernardi, L., Ryser, V.-A., \& Le Goff, J.-M. (2013). Gender role-set, family orientations, and women's fertility intentions in Switzerland. Swiss Journal of Sociology, 39(1), 9-31.

Booth, A., \& Amato, P. (1991). Divorce and psychological stress. Journal of Health and Social Behavior, 32(4), 396-407. https://doi.org/10.2307/2137106.

Boss, P. G. (1980). Normative family stress: Family boundary changes across the life-span. Family Relations, 29, 445-450.

Brockmann, H., \& Klein, T. (2004). Love and death in Germany: The marital biography and its effect on mortality. Journal of Marriage and Family, 66(3), 567-581. https://doi.org/10.2307/ 3600213.

Bronte-Tinkew, J., Allison, H., Scott, M. E., \& Johnson, D. (2009). Fathering with multiple partners: Links to children's well-being in early childhood. Journal of Marriage and Family, 71(3), 608-631. https://doi.org/10.2307/40262905.

Brown, S. L., Bulanda, J. R., \& Lee, G. R. (2005). The significance of nonmarital cohabitation: Marital status and mental health benefits among middle-aged and older adults. The Journals of Gerontology Series B: Psychological Sciences and Social Sciences, 60(1), S21-S29. https:// doi.org/10.1093/geronb/60.1.S21.

Brückner, H., \& Mayer, K. U. (2005). De-standardization of the life course: What it might mean? And if it means anything, whether it actually took place? Advances in Life Course Research, 9, 27-53. https://doi.org/10.1016/S1040-2608(04)09002-1.

Buber-Ennser, I. (2014). Attrition in the Austrian Generations and Gender Survey: Is there a bias by fertility-relevant aspects? Demographic Research, 31(16), 459-496. https://doi.org/10. 4054/DemRes.2014.31.16.

Buber-Ennser, I. (2015). Childrearing in Austria: Work and family roles. Journal of research in Gender Studies, 5(2), 121-146.

Bumpass, L. L., Ralley, R. K., \& Sweet, J. A. (1995). The changing character of stepfamilies: Implications of cohabitation and nonmarital childbearing. Demography, 32(3), 425-436.

Caselli, G., Drefahl, S., Wegner-Siegmundt, C., \& Luy, M. (2014). Future mortality in low mortality countries (world population \& human capital in the twenty-first century). Oxford: Oxford University Press.

Castro-Martín, T., Domínguez-Folgueras, M., \& Martín-García, T. (2008). Not truly partnerless: Non-residential partnerships and retreat from marriage in Spain. Demographic Research, 18 (16), 443-468.

Cherlin, A. J., \& Furstenberg, F. F., Jr. (1994). Stepfamilies in the United States: A reconsideration. Annual Review of Sociology, 20, 359-381. https://doi.org/10.2307/2083370.

Curtis, L. J. (2001). Lone motherhood and health status. Canadian Public Policy/Analyse de Politiques, 27(3), 335-356. https://doi.org/10.2307/3552473.

Curtis, L. J., \& Pennock, M. (2006). Social assistance, lone parents and health: What do we know, where do we go? Canadian Journal of Public Health/Revue Canadienne de Sante'e Publique, 97, S4-S10. https://doi.org/10.2307/41965615.

Davidson, K. (2002). Gender differences in new partnership choices and constraints for older widows and widowers. Ageing International, 27(4), 43-60. https://doi.org/10.1007/s12126002-1014-0. 
Davies, L., Avison, W. R., \& McAlpine, D. D. (1997). Significant life experiences and depression among single and married mothers. Journal of Marriage and Family, 59(2), 294-308. https:// doi.org/10.2307/353471.

Dawson, D. A. (1991). Family structure and children's health and well-being: Data from the 1988 national health interview survey on child health. Journal of Marriage and Family, 53(3), 573584. https://doi.org/10.2307/352734.

De Jong Gierveld, J. (2004). Remarriage, unmarried cohabitation, living apart together: Partner relationships following bereavement or divorce. Journal of Marriage and Family, 66(1), 236243. https://doi.org/10.1111/j.0022-2445.2004.00015.x.

Easterlin, R. A. (2006). Life cycle happiness and its sources: Intersections of psychology, economics, and demography. Journal of Economic Psychology, 27(4), 463-482. https://doi. org/10.1016/j.joep.2006.05.002.

Elder, G. H. (1995). The life course paradigm: Social change and individual development. In P. G. Moen, G. H. Elder, \& K. Lüscher (Eds.), Examing lives in context. Perspectives on the ecology of human development (pp. 101-139). Washington: American Psychological Association.

Elzinga, C. H., \& Liefbroer, A. C. (2007). De-standardization of family-life trajectories of young adults: A cross-national comparison using sequence analysis. European Journal of Population, 23(3-4), 225-250. https://doi.org/10.1007/s10680-007-9133-7.

Evenhouse, E., \& Reilly, S. (2012). Multiple-father families and welfare. Journal of Family Issues, 33(7), 966-995. https://doi.org/10.1177/0192513x11406496.

Franz, M., \& Lensche, H. (2003). Allein erziehend-allein gelassen? Die psychosoziale Beeinträchtigung allein erziehender Mütter und ihrer Kinder in einer Bevölkerungsstichprobe [Single parenthood-left alone? Phychosocial impairments of single mothers and their children in a population sample]. Zeitschrift für Psychosomatische Medizin und Psychotherapie, 49(2), 115-138. https://doi.org/10.2307/23870797.

Furstenberg, F. F. (1979). Recycling the family: Perspectives for researching a neglected family form. Marriage and Family Review, 2, 1-22.

Galobardes, B., Shaw, M., Lawlor, D. A., Lynch, J. W., \& Smith, G. D. (2006). Glossary: Indicators of socioeconomic position (part 1). Journal of Epidemiology and Community Health, 60(1), 7-12. https://doi.org/10.2307/40795066.

Goldman, N. (1993). Marriage selection and mortality patterns: Inferences and fallacies. Demography, 30(2), 189-208. https://doi.org/10.2307/2061837.

Gorman, B. K., \& Sivaganesan, A. (2007). The role of social support and integration for understanding socioeconomic disparities in self-rated health and hypertension. Social Science and Medicine, 65(5), 958-975. https://doi.org/10.1016/j.socscimed.2007.04.017.

Guzzo, K. B. (2009). Maternal relationships and nonresidential father visitation of children born outside of marriage. Journal of Marriage and Family, 71(3), 632-649. https://doi.org/10.2307/ 40262906.

Hanappi, D. (2012). Job insecurity and life satisfaction: Do parents' jobs hurt more?" Presented at the SCANCOR Seminar, School of Education, February 13, Stanford University, CA.

Hank, K., Deindl, C., \& Brandt, M. (2013). Changes in older Europeans' health across two waves of SHARE: Life-course and societal determinants. Journal of Population Ageing, 6(1-2), 8597. https://doi.org/10.1007/s12062-012-9076-6.

Harknett, K., \& Knab, J. (2007). More kin, less support: Multipartnered fertility and perceived support among mothers. Journal of Marriage and Family, 69(1), 237-253. https://doi.org/10. $2307 / 4622428$.

Heard, H. E., Gorman, B. K., \& Kapinus, C. A. (2008). Family structure and self-rated health in adolescence and young adulthood. Population Research and Policy Review, 27(6), 773-797. https://doi.org/10.2307/41217982.

Hemström, Ö. (1996). Is marriage dissolution linked to differences in mortality risks for men and women? Journal of Marriage and Family, 58(2), 366-378. https://doi.org/10.2307/353502. 
Heuveline, P., \& Timberlake, J. M. (2004). The role of cohabitation in family formation: The United States in comparative perspective. Journal of Marriage and Family, 66(5), 1214-1230. https://doi.org/10.2307/3600335.

Holmes, T. H., \& Rahe, R. H. (1967). The social readjustment rating scale. Journal of Psychosomatic Research, 11(2), 213-218. https://doi.org/10.1016/0022-3999(67)90010-4.

Hope, S., Power, C., \& Rodgers, B. (1999). Does financial hardship account for elevated psychological distress in lone mothers? Social Science and Medicine, 49(12), 1637-1649.

Horwitz, A. V., \& White, H. R. (1998). The relationship of cohabitation and mental health: A study of a young adult cohort. Journal of Marriage and Family, 60(2), 505-514. https://doi. org/10.2307/353865.

Idler, E. L., \& Benyamini, Y. (1997). Self-rated health and mortality: A review of twenty-seven community studies. Journal of Health and Social Behavior, 38(1), 21-37. https://doi.org/10. $2307 / 2955359$.

Joung, I. M. A., van de Mheen, H. D., Stronks, K., van Poppel, F. W. A., \& Mackenbach, J. P. (1998). A longitudinal study of health selection in marital transitions. Social Science and Medicine, 46(3), 425-435. https://doi.org/10.1016/S0277-9536(97)00186-X.

Karlsson, S. G., \& Borell, K. (2002). Intimacy and autonomy, gender and ageing: Living apart together. Ageing International, 27(4), 11-26. https://doi.org/10.1007/s12126-002-1012-2.

Khalaila, R., \& Litwin, H. (2014). Changes in health behaviors and their associations with depressive symptoms among Israelis aged 50+. Journal of Aging and Health, 26(3), 401-421. https://doi.org/10.1177/0898264313516997.

Koball, H. L., Moiduddin, E., Henderson, J., Goesling, B., \& Besculides, M. (2010). What do we know about the link between marriage and health? Journal of Family Issues, 31(8), 10191040. https://doi.org/10.1177/0192513X10365834.

Kohler, H.-P., Behrman, J. R., \& Skytthe, A. (2005). Partner + children = happiness? The effects of partnerships and fertility on well-being. Population and Development Review, 31(3), 407 445. https://doi.org/10.1111/j.1728-4457.2005.00078.x.

Liang, J. (1986). Self-reported physical health among aged adults. Journal of Gerontology, 41(2), 248-260.

Lillard, L. A., \& Panis, C. W. A. (1996). Marital status and mortality: The role of health. Demography, 33(3), 313-327. https://doi.org/10.2307/2061764.

Lillard, L. A., \& Waite, L. J. (1995). Til death do us part: Marital disruption and mortality. American Journal of Sociology, 100(5), 1131-1156. https://doi.org/10.2307/2782273.

Litwin, H., \& Sapir, E. V. (2009). Perceived income adequacy among older adults in 12 countries: Findings from the survey of health, ageing, and retirement in Europe. The Gerontologist, 49(3), 397-406. https://doi.org/10.1093/geront/gnp036.

Luy, M., \& Gast, K. (2014). Do women live longer or do men die earlier? Reflections on the causes of sex differences in life expectancy. Gerontology, 60(2), 143-153.

Marcussen, K. (2005). Explaining differences in mental health between married and cohabiting individuals. Social Psychology Quarterly, 68(3), 239-257. https://doi.org/10.1177/ 019027250506800304.

Marks, N. F. (1998). Does it hurt to care? Caregiving, work-family conflict, and midlife well-being. Journal of Marriage and Family, 60(4), 951-966. https://doi.org/10.2307/353637.

Mason, M. A., \& Kuhltau, K. (1989). Determinants of child care ideals among mothers of preschool-aged children. Journal of Marriage and Family, 74(4), 593-603.

Mastekaasa, A. (1997). Marital dissolution as a stressor: Some evidence on psychological, physical, and behavioral changes during the preseparation period. Journal of Divorce and Remarriage, 26(155-183).

McLanahan, S. S., \& Sandefur, G. (1994). Growing up with a single parent: What hurts, what helps. Cambridge, MA: Harvard University Press.

Mechanic, D., \& Hansell, S. (1987). Adolescent competence, psychological well-being, and self-assessed physical health. Journal of Health and Social Behavior, 28(4), 364-374. https:// doi.org/10.2307/2136790. 
Meyer, D. R., Cancian, M., \& Cook, S. T. (2005). Multiple-partner fertility: Incidence and implications for child support policy. Social Service Review, 79(4), 577-601. https://doi.org/ $10.1086 / 454386$.

Miller, R. B., Hollist, C. S., Olsen, J., \& Law, D. (2013). Marital quality and health over 20 years: A growth curve analysis. Journal of Marriage and Family, 75(3), 667-680. https://doi.org/10. 2307/23440908.

Myrskylä, M., \& Margolis, R. (2014). Happiness: Before and after the kids. Demography, 51(5), 1843-1866. https://doi.org/10.1007/s13524-014-0321-x.

Osborne, C., \& McLanahan, S. (2007). Partnership instability and child well-being. Journal of Marriage and Family, 69(4), 1065-1083. https://doi.org/10.2307/4622508.

Perelli-Harris, B., Berrington, A., Berghammer, C., Keizer, R., Lappegård, T., Mynarska, M., et al. (2014). Towards a new understanding of cohabitation: Insights from focus group research across Europe and Australia. Demographic Research, 31(34), 1043-1078.

Perelli-Harris, B., Kreyenfeld, M., Sigle-Rushton, W., Keizer, R., Lappegård, T., Jasilioniene, A., et al. (2012). Changes in union status during the transition to parenthood in eleven European countries, 1970s to early 2000s. Population Studies, 66(2), 167-182. https://doi.org/10.1080/ 00324728.2012 .673004$.

Perelli-Harris, B., \& Lyons-Amos, M. (2015). Changes in partnership patterns across the life course: An examination of 14 countries in Europe and the United States. Demographic Research, 33(6), 145-178.

Perrig-Chiello, P., \& Knöpfli, B. (2015). Forschungdossier: Trennung und Scheidung-im Längsschnitt (2012-2014). Bern: University of Bern.

Régnier-Loilier, A., Beaujouan, E., \& Villeneuve-Gokalp, C. (2009). Neither single, nor in a couple: A study of living apart together in France. Demographic Research, 21(4), 75-108. https://doi.org/10.4054/DemRes.2009.21.4.

Ren, X. S. (1997). Marital status and quality of relationships: The impact on health perception. Social Science and Medicine, 44(2), 241-249. https://doi.org/10.1016/S0277-9536(96)00158-X.

Ross, C. E., Mirowsky, J., \& Goldsteen, K. (1990). The impact of the family on health: The decade in review. Journal of Marriage and Family, 52(4), 1059-1078. https://doi.org/10.2307/353319.

Ross, C. E., \& Wu, C.-L. (1995). The links between education and health. American Sociological Review, 60(5), 719-745. https://doi.org/10.2307/2096319.

Scafato, E., Galluzzo, L., Gandin, C., Ghirini, S., Baldereschi, M., Capurso, A., et al. (2008). Marital and cohabitation status as predictors of mortality: A 10-year follow-up of an Italian elderly cohort. Social Science and Medicine, 67(9), 1456-1464. https://doi.org/10.1016/j. socscimed.2008.06.026.

Schneider, B., Rapp, I., Klein, T., \& Eckhard, J. (2014). Relationship status and health: Does the use of different relationship indicators matter? Global Public Health, 9(5), 528-537. https://doi. org/10.1080/17441692.2014.904917.

Schneider, G., Driesch, G., Kruse, A., Wachter, M., Nehen, H.-G., \& Heuft, G. (2004). What influences self-perception of health in the elderly? The role of objective health condition, subjective well-being and sense of coherence. Archives of Gerontology and Geriatrics, 39(3), 227-237. https://doi.org/10.1016/j.archger.2004.03.005.

Schüz, B., Wurm, S., Schöllgen, I., \& Tesch-Römer, C. (2011). What do people include when they self-rate their health? Differential associations according to health status in community-dwelling older adults. Quality of Life Research, 20(10), 1573-1580. https://doi. org/10.2307/41488225.

Stryker, S. (1980). Symbolic interactionism: A social structural version. Menlo Park, CA: Benjamin/Cummings.

Stutzer, A., \& Frey, B. S. (2010). Recent advances in the economics of individual subjective well-being. Social Research, 77(2), 679-714. https://doi.org/10.2307/40972234.

Thomson, E. (1997). Her, his, and their children: Influence on couple childbearing decisions. NSFH Working Paper No. 76, University of Wisconsin-Madison: Center for Demography and Ecology. 
Thomson, E. (2004). Step-families and childbearing desires in Europe. Demographic Research, Special Collection, 3, 117-134. https://doi.org/10.4054/DemRes.2004.S3.5.

Thomson, E. (2014). Family complexity in Europe. The ANNALS of the American Academy of Political and Social Science, 654(1), 245-258. https://doi.org/10.1177/0002716214531384.

Thomson, E., Hoem, J. M., Vikat, A., Buber, I., Prskawetz, A., Toulemon, L., et al. (2002). Childbearing in stepfamilies: How parity matters. In E. Klijzing \& M. Corijn (Eds.), Dynamics offertility and partnership in Europe: Insights and lessons from comparative research (Vol. II, pp. 87-99). New York and Geneva: United Nations.

Thomson, E., Lappegård, T., Carlson, M., Evans, A., \& Gray, E. (2014). Childbearing across partnerships in Australia, the United States, Norway, and Sweden. Demography, 51(2), 485508. https://doi.org/10.1007/s13524-013-0273-6.

Thomson, E., Winkler-Dworak, M., Spielauer, M., \& Prskawetz, A. (2012). Union instability as an engine of fertility? A micro-simulation model for France. Demography, 49(1), 175-195.

Treviño, R., \& Gumà, J. (2013). De la monoparentalidad a la reconstitución familiar: Un análisis a partir de fuentes transversales. Papers: Revista de Sociologia, 98(2), 287-309.

Turney, K., \& Carlson, M. J. (2011). Multipartnered fertility and depression among fragile families. Journal of Marriage and Family, 73(3), 570-587. https://doi.org/10.2307/29789603.

Uhlenberg, P., \& Mueller, M. (2003). Family context and individual well-being. In J. T. Mortimer \& M. J. Shanahan (Eds.), Handbook of the life course (pp. 123-148, Handbooks of Sociology and Social Research). New York: Springer US.

Umberson, D., Williams, K., Powers, D. A., Liu, H., \& Needham, B. (2006). You make me sick: Marital quality and health over the life course. Journal of Health and Social Behavior, 47(1), 1-16. https://doi.org/10.2307/30040295.

Van de Velde, S., Bambra, C., Van der Bracht, K., Eikemo, T. A., \& Bracke, P. (2014). Keeping it in the family: The self-rated health of lone mothers in different European welfare regimes. Sociology of Health \& Illness, 36(8), 1220-1242. https://doi.org/10.1111/1467-9566.12162.

Vikat, A., Thomson, E., \& Hoem, J. M. (1999). Stepfamily fertility in contemporary Sweden: The impact of childbearing before the current union. Population Studies, 53(2), 211-225.

Vingilis, E., Wade, T. J., \& Adlaf, E. (1998). What factors predict student self-rated physical health? Journal of Adolescence, 21(1), 83-97. https://doi.org/10.1006/jado.1997.0131.

Voydanoff, P. (2005). Toward a conceptualization of perceived work-family fit and balance: A demands and resources approach. Journal of Marriage and Family, 67(4), 822-836. https:// doi.org/10.2307/3600241.

Wadsworth, M. E. J. (1997). Health inequalities in the life course perspective. Social Science and Medicine, 44(6), 859-869. https://doi.org/10.1016/S0277-9536(96)00187-6.

Wahrendorf, M., \& Siegrist, J. (2010). Are changes in productive activities of older people associated with changes in their well-being? Results of a longitudinal European study. European Journal of Ageing, 7(2), 59-68. https://doi.org/10.1007/s10433-010-0154-4.

Waldron, I. (2000). Trends in gender differences in mortality: Relationships to changing gender differences in behaviour and other causal factors. In E. Annandale \& K. Hunt (Eds.), Gender inequality in health (pp. 150-181). Buckingham: Open University Press.

Witvliet, M. I., Arah, O. A., Stronks, K., \& Kunst, A. E. (2014). A global study on lone mothers: Exploring the associations of self-assessed general health with motherhood types and gender inequality in 32 countries. Women's Health Issues, 24(2), e177-e185. https://doi.org/10.1016/j. whi.2013.12.001.

Woo, H., \& Zajacova, A. (2015). Examination of age variations in the predivtive validity of self-rated health. Paper presented at the Population Association of America (PAA) 2015, San Diego, 
Open Access This chapter is licensed under the terms of the Creative Commons Attribution 4.0 International License (http://creativecommons.org/licenses/by/4.0/), which permits use, sharing, adaptation, distribution and reproduction in any medium or format, as long as you give appropriate credit to the original author(s) and the source, provide a link to the Creative Commons license and indicate if changes were made.

The images or other third party material in this chapter are included in the chapter's Creative Commons license, unless indicated otherwise in a credit line to the material. If material is not included in the chapter's Creative Commons license and your intended use is not permitted by statutory regulation or exceeds the permitted use, you will need to obtain permission directly from the copyright holder.

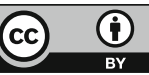

